\title{
A normatização da pobreza: crianças abandonadas e crianças infratoras*
}

\section{Carmen Sylvia Vidigal Moraes}

Faculdade de Educação, U niversidade de São Paulo

\section{Introdução}

Nos últimos anos do século XIX e nas primeiras décadas do século XX, a ação pedagógica dos setores dominantes, ao lado de outras práticas mais diretamente repressivas, estará voltada para a "reconstrução nacional”, a conformação da cidadania, e para a questão da organização do trabalho. São desenvolvidas inúmeras estratégias e dispositivos visando a moralização e o ajustamento do trabalhador à nova ordem social.

A partir dos anos 70 do século passado, a fisionomia urbana de São Paulo começa a transformar-se. A expansão da economia cafeeira, a riqueza gerada pelo café e a série de empreendimentos decorrentes ampliaram o setor de serviços urbanos, os empregos no comércio, na indústria nascente e na burocracia e provocaram um brusco crescimento populacional. A presença de fazendeiros enriquecidos que, cada vez mais, faziam da cidade sua residência principal, assim como o aumento da massa de assalariados, constituída principalmente por imi-

* O tema analisado faz parte de pesquisa mais ampla realizada pela autora (Moraes, 1990). grantes europeus, mudam lenta e inexoravelmente o aspecto físico e os hábitos culturais de São Paulo.

Com a aprovação do subsídio governamental à imigração, em 1885, a entrada de imigrantes no país aumenta substancialmente. Entre 1882 e 1886, chegam a São Paulo 17.460 imigrantes; em 1887 o total atinge 27.323; e, ao abolir-se a escravidão, o contingente havia superado oitenta mil pessoas (Petrone, 1976; Sallum, 1982).

A intervenção do Estado e a socialização dos custos de formação da força de trabalho favoreceram o surgimento de condições para que se instituíssem o trabalho livre e o mercado de trabalho. ${ }^{1} \mathrm{O}$ subsídio do governo adquire significado especial para a continuidade do processo de formação do proletariado no Brasil, na medida em que significou o abandono de certas formas violentas de sujeição do trabalho - como a fixação compulsória do trabalhador pelo endividamento - por outras formas "politicamente mais viáveis e economicamente mais rentáveis" (Sallum, 1982).

\footnotetext{
${ }^{1}$ A esse respeito consultar Kowarick (1987) e Martins (1979).
} 
De ora em diante, a sujeição do trabalhador tenderia a dar-se principalmente através da coação econômica apoiada na ausência de meios de produção de sua propriedade. Dessa maneira, o Brasil adequava sua legislação aos padrões ideológicos liberais instituídos nas sociedades capitalistas onde vigorava o igualitarismo formal - imposto pelo direito burguês - nas relações contratuais entre o capital e o trabalho (Sallum, 1982).

Os anos iniciais da década de 90 caracterizam-se pela discussão e organização das medidas a serem implementadas pelo novo governo republicano a fim de que se criassem, no país, as condições propícias à vinda dos trabalhadores europeus. ${ }^{2}$ A mais insistente das reivindicações, aquela considerada de "importância capital", a "primeira das medidas", era o saneamento das cidades mais atingidas pela epidemia de febre amarela, como Campinas e Santos. ${ }^{3}$ Neste sentido, o Congresso Legislativo aprova verbas vultosas para a higiene pública, pois - como afirma o então deputado Gabriel Prestes compreende-se que "a propagação das epidemias importaria na interrupção das correntes imigratórias que vivificam o ubérrimo solo paulista". ${ }^{4}$ Projetos de lei, visando a reforma do serviço sanitário e a elaboração de um Código que normatizasse esses serviços, tramitavam no Congresso. Na capital, onde fora organizada uma Comissão de Saneamento sob a direção de João Pereira Ferraz, realizavam-se inúmeras obras. Nas regiões mais

${ }^{2}$ De acordo com os dados oficiais publicados no jornal A Província de São Paulo (doravante A PSP), em 28/1/1892, haviam entrado no porto de Santos, durante o ano de 1891, 86.754 imigrantes. Entre 1882 e 1891, este total atingira 176.442 pessoas. As entradas na hospedaria de São Paulo, dirigida pela Sociedade Promotora da Imigração, foram: em 1891, 108.736 e de 1881 a 1891, 221.657 trabalhadores. O fim da década de 80 e a década de 90 constituíram um período de grande expansão da lavoura cafeeira, o que significou grande procura de braços. Em 1890, o estado ressentia-se "da falta de braços na lavoura", do esvaziamento da Hospedaria dos Imigrantes e com o "desânimo nos promotores da imigração" (A PSP, 30/5/1890). $\mathrm{O}$ ano de 1891, em que se registra o maior número de imigrantes para o Brasil, não será o melhor ano para São Paulo. O maior contingente anual registrado deu-se em 1895, quando entraram 139.998 pessoas. Ver Sallum (1982) e Petrone (1976).

${ }^{3}$ A PSP, Editorial, O Grande Auxílio, 28/5 e 30/5/1890.

${ }^{4}$ O Estado de S. Paulo (doravante O ESP), 11/06/1893. críticas da cidade, que não ofereciam nenhuma qualidade de vida e onde se "amontoavam" os trabalhadores, como a várzea do Carmo - freqüentemente invadida pelas águas do Rio Tamanduateí -, o Bom Retiro, o Brás, Pari e circunvizinhanças, foram feitos serviços de drenagem superficial, "a limpeza e desobstrução de valas antigas e até de bueiros em arco, construídos e aterrados por conveniência individual, a abertura de valetas ou sarjetas laterais de ruas". ${ }^{5}$

Enfim, a política sanitarista praticada pelo Estado define uma série de medidas profiláticas de intervenção no espaço urbano para a eliminação dos focos epidêmicos, como a instalação da rede de esgotos, canalização da água, eliminação de becos insalubres, abertura de novas ruas e organização de todo um sistema público de serviços de higiene. E se, por um lado, as campanhas de saneamento e as práticas médicas podem desempenhar imediatamente a função de garantir a saúde das pessoas que, por sua pobreza, estavam impedidas de receber tais cuidados, por outro lado, elas consistem na organização de estratégias fortemente autoritárias de controle dos dominantes sobre a população pobre e trabalhadora, visando torná-la mais apta ao trabalho. Através da inculcação de hábitos de higiene, normas de saúde, justificadas e legitimadas pelas recentes descobertas da ciência, a medicina urbana adotada pelo Estado no final do século dezenove procura disciplinar os trabalhadores e eliminar os perigos que eles representavam tanto à saúde dos dominantes como à sua propriedade.

É muito forte o objetivo pedagógico e moralizador atribuído pelo discurso médico às práticas higiênicas, cuja vulgarização era vista como uma espécie de guerra santa contra "a ignorância, a miséria, a rotina, a superstição, a má tradição" e toda a sorte de "prejuízos" resultantes "dos maus hábitos inveterados". No discurso da medicina higienista e da engenharia sanitária, a doença assume a dimensão de problema econômico, político e moral. A "higiene da alma" estava diretamente associada à higiene do corpo, e transmitir noções de higiene e saúde ao "povo" - sempre infantilizado ou visto como portador de "maus instintos" - significava "emancipá-

\footnotetext{
${ }^{5}$ O ESP, $21 / 02 / 1893$ e 11/06/1893.
} 
lo", evitando "toda e qualquer degradação física ou moral". ${ }^{6}$

Como parte das medidas preventivas, criam-se critérios de seleção tanto para a entrada como para a permanência dos imigrantes que aqui já se encontravam. Dessa maneira, pensava-se eliminar os "elementos pervertidos e maus", os "estrangeiros perigosos". ${ }^{7}$ Além disso, era preciso garantir - como alertava $O$ Estado de $S$. Paulo - que os imigrantes viessem para "servir à agricultura". Reivindicava-se, pela imprensa, que as empresas de imigração organizassem um trabalho de "severa fiscalização", ${ }^{8}$ providenciando para que fossem canalizados para São Paulo os trabalhadores sem recursos, agricultores, que possuíssem ligações prévias de amizade ou parentesco no estado e que viessem organizados em famílias, "de modo a romperem com os vínculos fundamentais de parentesco com o país de origem" (Sallum, 1982). Outro tipo de seleção estava também em curso: o da nacionalidade do imigrante, evidenciando a presença de concepções eugênicas e de preconceitos raciais que se tornarão mais fortes a cada dia.

É preciso enfatizar que, apesar de, em São Paulo, o imigrante ser largamente majoritário nos vários ramos da economia urbana, particularmente nas atividades fabris, constituindo-se no principal segmento do proleta-

${ }^{6}$ O ESP, Saneamento da Cidade de São Paulo - XV, por M. Arruda, 19/06/1893; e Editorial, Serviço Sanitário, 17/08/1893.

${ }^{7} \mathrm{O} E S P$, Anarquismo, 03/05/1893.

${ }^{8} O$ ESP, Editorial, A Imigração, 26/2/1893. O editorial afirma ser necessário atentar para a modificação dos critérios de seleção dos imigrantes, "uma vez que poucos são os que de fato servem à agricultura, vindo muitos operários, profissionais liberais e vagabundos, o que prejudica nossa situação". Além disso, era preciso "atentar para os levantes populares em nome do socialismo e do anarquismo, que também pode nos prejudicar". Em outro editorial, publicado a 26/10/ 1893, Bordéis, "Caftens" e Usura, o jornal transmite seu apoio ao chefe de polícia de São Paulo, Theodoro de Carvalho, que havia tomado medidas para a deportação "de certos gatunos audaciosos e 'caftens' que aqui haviam assentado as suas tendas de combate com o intuito de explorarem o roubo e a prostituição". É exatamente nesta época que a Sociedade Promotora da Imigração elabora a aplicação de questionários a serem respondidos pelos fazendeiros, com o objetivo de levantar dados que a auxiliassem "nos trabalhos" com a imigração ( $O E S P, 20 / 04 / 1893)$. riado em formação, não se pode esquecer a presença dos nacionais pobres e libertos na constituição do mercado livre de trabalho. Para o parque industrial que se desenvolvia em São Paulo, o braço estrangeiro dispensou o trabalhador nacional. À semelhança das regiões prósperas do café, também na indústria o trabalhador autóctone foi incorporado de maneira acessória e residual (Hardman, 1988; Kowarick, 1987). O segmento nacional, vítima de fortes preconceitos raciais - principalmente o trabalhador negro e o mestiço que traziam "estampada na pele a pecha que a escravidão tão fortemente sedimentara" -, foi considerado inapto e indisciplinado para o trabalho. A ele couberam os serviços mais aviltados, como o emprego doméstico e outras atividades classificadas como "mal definidas" e "não declaradas", nas quais certamente estavam incluídos o trabalho pesado e o ocasional, que tarefeiros de todo o tipo praticavam na cidade dos primórdios da industrialização (Kowarick, 1987).

Os receios provocados pelo "aumento extraordinário" da mendicidade, da horda de desocupados e "vadios"que, apesar da ação da polícia, percorriam "as ruas da cidade implorando a caridade pública" - levam a classe dominante a tomar medidas para coibir a permanência dos "inválidos para o trabalho". É também providenciada a criação - tanto por parte do Estado como da iniciativa privada - de inúmeras instituições de assistência, os denominados asilos: asilos para mendigos, para alienados, para órfãos, para tuberculosos etc. ${ }^{9}$

${ }^{9}$ Em 1893, o poder legislativo autoriza a criação do asilo dos alienados, "perto da estação do Juquery". Na capital existia apenas um hospício, superlotado e sem as condições de higiene adequadas. No interior do estado, os doentes eram recolhidos às cadeias. Segundo $O$ ESP, o governo não deveria adiar por mais tempo a organização de "estabelecimento construído de acordo com as prescrições da ciência moderna". "Os loucos - dirão - merecem toda a nossa comiseração" ( $O E S P, 10 / 5 / 1893)$. Nessa mesma época, são organizados, na Santa Casa da Misericórdia, o asilo da mendicidade e, anexo a ele, o Externato São José, para meninas pobres e órfãs. Em 1893, o asilo mantinha entre homens e mulheres - 121 pessoas, 43 nacionais e 78 "estrangeiros". No mesmo ano, o Externato abrigava 365 alunas, 338 nacionais e 27 “estrangeiras" (O ESP, 22/8, 13/9 e 9/11/1893). Em 1899, Clemente Ferreira organiza um Sanatório popular "para o isolamento e tratamento de tuberculoses pobres" (O ESP, 25/6/1899). 
O objetivo de isolar do convívio social os indivíduos considerados improdutivos é claramente explicitado no discurso dos dominantes. Ponderavam que, embora fosse preciso aplicar quantias mais ou menos vultosas nestes empreendimentos, haveria, "em compensação", "a vantagem de afastar do seio de nossa sociedade elementos inúteis e muitas vezes perniciosos". ${ }^{10}$ Uma vez tomadas as medidas capazes de selecionar somente o trabalhador "pacífico" e "morigerado" e de afastar os "maus elementos", estavam dadas as condições para o desenvolvimento das indústrias e o progresso do país.

\section{Osprimeirostempos}

É nesta "sociedade abandonada, privada de possibilidades", que se defronta com as crianças órfãs, abandonadas, infratoras, filhas de pais pobres, oprimidos, explorados. "Crianças e adultos abandonados", transformados em "população sobrante" pela forma assumida pelo desenvolvimento capitalista (Martins, 1991).

Os setores dirigentes sempre demonstraram apreensão com o crescente número de crianças desamparadas, habitantes das ruas da cidade. Para elas providenciou asilos e reformatórios, instituições moralizadoras, onde o trabalho se constituía em importante recurso pedagógico.

Os relatórios da administração provincial indicam que, no início do século XIX, a infância abandonada constituía um grave problema social, sendo freqüentes os casos de recém-nascidos abandonados pelas mães em virtude da penúria de sua situação econômica, agravada pela inexistência de oportunidades de trabalho para as mulheres e pela ausência do pai (Pena, 1981).

Nesta época, o campo de assistência social reduzia-se ao setor médico hospitalar, representado pela Santa Casa da Misericórdia, e por outras poucas obras, como

${ }^{10} \mathrm{O} E S P$, A mendicidade, 10/5/1893. O jornal classifica os mendigos em dois tipos. Do primeiro tipo fazem parte os indivíduos "dignos de comiseração pela invalidez em que se acham e pela miséria que padecem”. Os outros não passavam "de vagabundos, sem coragem para o trabalho e afeitos ao rebaixamento moral de mendigar". Aos primeiros recomendava o internamento em asilos; quanto aos segundos, deveria a polícia exercer "a ação moralizadora que a lei lhe faculta". o Lazareto, fundado pelo governo provincial, em 1802. Com o objetivo de resolver o problema, o então presidente da Província, Lucas A. M. de Barros, Barão de Congonhas do Campo, cria, em 1825, a Casa da Roda ou Casa dos Expostos e a instala no pavimento térreo da Santa Casa da Misericórdia. O Asilo do Expostos era também chamado de Casa da Roda em alusão ao dispositivo nela existente, uma roda que, girando em torno de um eixo perpendicular, ocupava toda uma janela - sempre aberta do lado de fora, de modo que quem desejasse se desfazer de uma criança pudesse depositá-la na caixa e, movimentando a roda, passá-la para o interior do prédio.

Na mesma ocasião, o governo da Província funda, na capital, em 1824, o asilo para meninos órfãos - o Seminário de Sant'Anna -, e, em 1825, para as meninas, o Seminário da Glória.

\section{O Instituto de EducandosArtífices}

O Instituto de Educandos Artífices, criado em 1874, veio substituir o Seminário dos Educandos de Sant'Anna, extinto em 1868. ${ }^{11}$ Organizado em companhia militar anexa ao corpo policial, de rígido caráter disciplinar, essa instituição dispunha-se a "facilitar ao menino po-

${ }^{11} \mathrm{O}$ Seminário dos Educandos de Sant'Anna foi extinto pela lei número 57, de 18 de abril de 1868. Em 1869, o então vice-presidente de São Paulo, Vicente Pires da Motta, assina a lei criando uma companhia de menores na Força Policial, para a qual seria providenciada a "instrução primária e ensino de ofícios mecânicos". Somente em 1874 o governo dá-lhe regulamento, aprovado pela lei n. 52, de 24 de abril. A Casa dos Educandos de Sant'Anna fora criada em 1844 e, segundo Celso Suckow da Fonseca (1961, p. 310), abrigava os “órfãos e meninos pobres", maiores de 6 anos, aos quais seria destinado o ensino das primeiras letras. $\mathrm{O}$ autor deduz que as crianças ali recolhidas também aprendiam ofícios, embora no regulamento não constasse nenhuma determinação de ser o estabelecimento destinado a essa modalidade de aprendizagem. A parte prática fazia-se, quando possível, em oficinas particulares, pois a Casa dos Educandos não possuía oficinas próprias. É o que indica a existência de contratos entre o governo e particulares, como no caso do sr. João Guilherme Einsbgler, por exemplo, ao qual foi destinado, “como auxílio à sua fábrica de fundição e galvanismo a quantia de 6 contos de réis, obrigando-se ele a manter em dita fábrica, como aprendizes, oito meninos maiores de 12 anos do Seminário de Sant'Anna". 
bre e desvalido a sua educação industrial, impedindo assim que por falta dela se desviem do amor ao trabalho e se tornem maus e prejudiciais cidadãos". ${ }^{2}$

Para a admissão dos meninos pobres, algumas preferências não poderiam ser preteridas sob pretexto algum: seriam aceitos, em primeiro lugar, "os filhos legítimos de voluntários da pátria, de militares, de guardas nacionais e de soldados do cargo policial, que houverem servido na guerra contra o Paraguai"; em segundo, "os órfãos de pai"; em terceiro, "os órfãos de pais pobres, ainda que vivos". Os educandos artífices - que deveriam ser maiores de dez anos e menores de catorze também deveriam apresentar "condições sanitárias satisfatórias" e serem vacinados.

O Seminário estava organizado como caserna. Dentro e fora da casa os educandos obedeciam a um regime militar adaptado, com postos de graduação semelhantes aos existentes no exército, de forma a que o sistema de emulação provocasse neles o incentivo à "melhor conduta" e "maior adiantamento", ambos premiados no final do ano, durante as festas de encerramento, na presença do Presidente da Província e de demais autoridades da administração.

A exemplo das práticas militares, diariamente, como bons soldados, os meninos trajavam uniforme militar; nos dias de parada, "Te Deum" ou festa nacional, compareciam "em uniforme e com o maior asseio". Nos domingos e dias santos, eram conduzidos pelo diretor até a igreja do colégio, e lá "ouviam a missa dita pelo capelão do estabelecimento".

Todos os alunos eram internos. Com o consentimento do diretor, podiam sair a passeio para visitar a família em um domingo de cada mês, sempre acompanhados por outro educando indicado pelo diretor. O Regulamento procurava estender o controle do instituto para fora dos muros da escola e proibia terminantemente que, nos passeios, o menino entrasse em "tavernas" ou saísse acompanhado por pessoas estranhas ou não autorizadas pelo diretor. Nenhum educando podia abandonar o internato

${ }^{12}$ Regulamento do Instituto dos Educandos Artífices, aprovado pela lei n. 52, de 24 de abril de 1874 . Entre 1840 e 1865 , foram criadas, no Império, dez casas de educandos, cda qual funcionando numa capital de prvíncia. A este rspeito, ver Cunha (1977). antes de completar 20 anos, a no ser em caso de moléstia contagiosa ou requisito de parente. Nesse caso, o estabelecimento devia ser indenizado em dinheiro.

O diretor, nomeado pelo Presidente da Província, subordinava-se exclusivamente a este. Deveria ser casado e residente na casa, maior de 40 anos, e militar com patente não inferior a capitão, se do exército, ou superior a tenente, se da Guarda Nacional. ${ }^{13}$

No cumprimento de seu dever, no exercício do poder disciplinar, cabia ao diretor aplicar penas aos alunos, e estas variavam conforme a gravidade atribuída ao ato: repreensão - em particular ou na presença do corpo de educandos -, privado do recreio e dos passeios de fins de semana, exclusão da mesa às refeições, variadas formas (não explicitadas) de "correção moral" e, até mesmo, a prisão, durante um máximo de oito dias, no xadrez da casa. Embora as tais práticas não estejam especificadas, é provável que elas se pautassem no Regulamento, de 1844, quando os castigos corporais foram banidos e substituídos por outros procedimentos capazes de "ofender o amor próprio e o estímulo infantil e criar emulação"; ou seja, por técnicas de humilhação e exclusão: "sendo graves as faltas, reclusão solitária no escuro ou retirado"; "estar sentado no banco de desprezo, em que seja pintada a figura de um burro", durante o período de aulas; "trazer sobre o ventre atado à cintura com barbante, um papel com letreiro em maiúsculo de VADIO - ou - DESCUIDADO - ou - DESORDEIRO -

${ }^{13}$ De acordo com o Regulamento, os empregados do estabelecimento eram de "duas classes": os nomeados pelo presidente da província - diretor, médico, capelão, professores, escrivão e almoxarife; os de nomeação do diretor - mestre de oficina, agente, amanuense, enfermeiro, porteiro e empregados internos em geral. Todos os funcionários de primeira classe deveriam ser brasileiros; os de segunda, "na falta absoluta de nacionais igualmente aptos", poderiam ser estrangeiros, com exceção do amanuense. Exceto o professor de primeiras letras, sempre "um dos mais habilitados entre os atualmente providos em algumas cadeiras desta capital", os outros professores e mestres, em falta de nomeação, seriam designados pelo diretor, com aprovação do presidente da província, por três anos. Os maiores vencimentos eram os recebidos pelo diretor $(2.400 \$ 000)$, seguidos pelo escrivão (1.600\$000), almoxarife, professores (exceto o de primeiras letras) e mestres (1.200\$000). Os salários do médico e do enfermeiro eram respectivamente $1.000 \$ 000$ e $600 \$ 000$. 
ou - COMILÃO ou outra qualquer palavra que publique o vício, defeito ou culpa" (Laurindo, 1962). Em caso de falta grave, o castigo era o "assentamento de praça no exército ou armada imperial". ${ }^{14}$ Fatos reconhecidos como criminosos seriam julgados segundo o Código Criminal do Império. ${ }^{15}$

Neste tipo de instituição voltado para a socialização dos setores populares, o espaço concedido aos alunos, a organização do tempo de trabalho e de lazer são planejados de maneira que cada um dos internos saiba que está sob vigilância constante, habituando-o "a fazer uso ordenado e regrado do espaço e do tempo" (Grignon, 1971, p. 15).

O Instituto de Educandos Artífices contava com as seguintes escolas e oficinas: primeiras letras; geometria e mecânica aplicada às artes; noções gerais de aritmética e álgebra; escultura e desenho aplicado às artes; música e instrumentos de corda; ginástica, natação e jogo de armas; alfaiate, sapateiro, marceneiro, serralheiro, correeiro, "e outras mais que o governo achar conveniente, sob proposta do diretor". Além destas aulas estava previsto, três vezes por semana, o ensino dos exercícios militares.

Os exames eram realizados ao final de cada ano, presididos pelo diretor, com a assistência de um comissário do governo e do Inspetor da Instrução Pública. Havia exposição anual dos trabalhos produzidos, com distribuição de prêmios e medalhas de prata por capacidade "moral", "intelectual" e "industrial". O educando deveria usar a medalha para sair na rua ou em "formatura de corpo".

${ }^{14}$ São bastante conhecidas a rigidez da hierarquia, a dureza das normas que vigoravam nas corporações militares, a extrema crueldade e violência no tratamento dos soldados e marinheiros. Após a República, inúmeras reformas são feitas na Força Policial da Província de São Paulo no sentido de modernizá-la, inclusive com a instalação de cursos de primeiras letras para praças e soldados, além da vinda de oficiais franceses para treinamento e preparo de oficiais brasileiros. No entanto, a armada nacional será mais renitente na manutenção das velhas e preconceituosas normas, só iniciando uma reforma em sua organização após inúmeras revoltas armadas dos marinheiros. A esse respeito, consultar Fernandes (1977) e Carvalho (1977).

${ }^{15}$ Pelo Código Criminal do Império, os menores não estavam isentos de processo penal.
O conjunto das disposições legais aqui apresentadas indica a vontade dos grupos dirigentes no que se refere ao tratamento institucional a ser dado à infância pobre, órfã ou abandonada. No entanto, a análise do funcionamento destes estabelecimentos, propiciada pela leitura dos jornais da época, ${ }^{16}$ sugere que suas condições reais de existência não eram aquelas pretendidas pelos regulamentos internos. Este é o caso do Instituto de Educandos Artífices.

Apesar dos objetivos proclamados, o estabelecimento debateu-se com a exigüidade crônica de recursos durante os tempos do Império. Observa-se o descompasso entre os objetivos anunciados e as recomendações propostas pelos presidentes provinciais no sentido de melhor preparar os jovens e o comportamento da Assembléia que, ano após ano, negava a solicitação de verbas para criação de novos cursos ou a manutenção de oficinas práticas de aprendizagem.

Em 1876, por exemplo, o Presidente da Província solicita inutilmente à Assembléia recursos para a instalação de uma oficina tipográfica, o provimento da cadeira de geometria e mecânica aplicada às artes e a criação de uma cadeira de língua francesa, considerada de muito utilidade, já que na época não existiam livros ou manuais técnicos em português e a maioria dos adotados era de autores franceses. Duas oficinas teriam funcionado com certa regularidade, a de marcenaria e a de alfaiate. ${ }^{17}$

${ }^{16} \mathrm{O}$ principal órgão informativo existente na Província de São Paulo em 1874 era o Correio Paulistano. De convicção liberal, tinha por redator chefe e proprietário Joaquim Roberto de Azevedo Marques. Neste mesmo ano, o republicano Américo de Campos, que fazia parte do corpo de redatores, despede-se do jornal para criar $A$ Província de São Paulo. No ano seguinte, aparece o nome de Leôncio de Carvalho como único proprietário, para logo a seguir o Correio comunicar que outros "correligionários políticos" do Partido Liberal haviam se associado ao jornal.

${ }^{17} \mathrm{Em} 1 / 2 / 1877$, a direção do Instituto faz publicar na seção de “Anúncios" de A PSP, a comunicação de estarem à venda no estabelecimento os seguintes produtos produzidos em suas oficinas: "dúzias de cadeiras envernizadas (64\$000); aparador, um par (40\$000); sofaletes $(25 \$ 000)$ ". Aprontava-se "por medida e com brevidade": "calças de pano $(4 \$ 000)$; coletes de pano $(4 \$ 000)$; calças de brim ( $3 \$ 500)$; paletós de brim ( $3 \$ 000)$; ditos de pano de soque $(12 \$ 000)$; paletó sobre (20\$000)". 
Tais fatos, ao lado do descaso com a instrução pública no período, são indicativos da desatenção do Governo Provincial em relação a uma atitude mais decisiva no âmbito do processo de constituição de um mercado de trabalhadores nacionais e livres. ${ }^{18}$ No entanto, não se deve minimizar a importância dos órfãos e desvalidos na composição da força de trabalho, pois, como observam Stein (1979) e Hardman (1988), eles estiveram presentes "na abertura das primeiras ferrovias, no alargamento dos portos e nos primeiros ofícios manufatureiros". ${ }^{19}$

O Estado, segundo esses autores, sabia de sua importância: foram eles que compuseram os quadros das companhias militares da armada brasileira, lutaram e morreram na Guerra do Paraguai, e "dessas camadas projetou-se a constituição de um aparelho militar do tipo

${ }^{18}$ O Presidente da Província tece os seguintes comentários: "O desenvolvimento intelectual em nossa província não alcançou ainda o nível do progresso material. A população calculada em 837.354 habitantes, e destes 696.131 jazem nas trevas da ignorância. Temos 462 escolas providas, e só apenas freqüentadas por 10.826 alunos, o que dá 23 a cada uma. São verdades que pesa-me anunciar, pois só agradar podem ao proprietário da taverna: ele é o único protegido da ignorância; todas as indústrias desenvolvem-se com o calor da instrução". A PSP, Seção Administrativa. Extratos do Relatório da Presidência, 09-02-1877.

${ }^{19}$ De acordo com Stein (1979, p. 66), “os empresários da indústria têxtil recrutavam a sua mão-de-obra não especializada nos orfanatos, nos juizados de menores, nas Casas de Caridade e entre os desempregados das cidades do litoral. Ao se utilizarem dessas fontes de mão-de-obra, os proprietários das fábricas asseguraram o desenvolvimento de um segmento industrial da economia brasileira, convertendo-se, ao mesmo tempo, em benfeitores e filantropos; ambos os papéis estavam entrelaçados, e disso tinham plena consciência os empresários e os observadores da época. [...] Os empresários tinham a visão ampla e difundida de que os pobres eram uma classe dada à indolência se não fosse coagida a trabalhar. Foi com grande satisfação que os editores de um jornal da província de São Paulo saudaram a fundação da fábrica São Luís, em 1869, que empregava 'crianças e mulheres [...] nas máquinas, as primeiras empregando o tempo desperdiçado no ócio em trabalho útil e as mulheres empregando o seu tempo de modo mais vantajoso"”. Segundo concepção da época, "o trabalho remunerado de 'centenas de órfãos e crianças abandonadas' nos asilos, nas instituições de Irmãs de Caridade e nas sociedades beneficentes iria substituir a 'caridade privada' e aliviar o ônus fiscal da sociedade". moderno”. De forma coerente, “o Império brasileiro expunha as companhias de aprendizes e outros institutos congêneres no rol das criações nacionais [...]. Já em 1876, por exemplo, no livro que apresentava oficialmente o Brasil na Exposição Universal da Filadélfia, lá estavam os estabelecimentos de caridade (que incluíam asilos de desvalidos, além de santas casas, leprosários e hospícios) e lá estava, com destaque, o item relativo às casas de correção, oferecendo dados sobre a produção das oficinas desses presídios [...] concluindo, afinal, que o sistema penitenciário preferível 'e mais em harmonia com os preceitos da ciência', é aquele que melhor equaciona o generoso empenho de fazer da pena, também, meio de educação" (Hardman, 1988, p. 91). ${ }^{20}$

\section{O Seminário da G lória}

Ao lado de inúmeros asilos destinados a meninas órfãs e abandonadas mantidos pela iniciativa particular, o governo da Província sustentou apenas um, o Seminário da Glória. Seus primeiros estatutos definem como objetivo da instituição atender à "mísera orfandade do sexo feminino cuja pobreza, poderoso veículo de tantos costumes e vícios que desgraçadamente transmitidos pelas mães às filhas tanto influem na depravação e estraga geral dos costumes". ${ }^{21}$

A função moralizadora da instituição está, como se pode ver, claramente explicitada. Tanto ou mais que o homem, a mulher - sobretudo a das camadas populares - é vista como portadora de perversão e degenerescência. Abandonada a si mesma, à "sua própria natureza”, tornar-se-ia inevitavelmente escrava de suas paixões e vícios.

Como sucedâneo do caráter militar das instituições para meninos, os estabelecimentos femininos apresentam-se organizados segundo o modelo do convento. Até

${ }^{20}$ Barão de Itajubá, "Protection de l'enfance”. In: Nery, SantaAnna (dir.), Le Brésil en 1889, Paris: Charles Delagrave, 1889, apud HARDMAN, 1988.

${ }^{21}$ Estatutos de 10 de agosto de 1825, APESP, Registro de Documentos de Ouro enviados ao Ministério Público, 1820-1847, Livro 216, lata 78, $\mathrm{n}^{\circ}$ de ordem 436, cap. 3, p.36, cit. por Borges (1980). 
1870, o Seminário era um estabelecimento leigo, dirigido por senhoras nomeadas pelo Presidente da Província. Mas, a partir de 1871, inicia-se sua segunda fase, quando a casa é entregue aos cuidados de uma Ordem Religiosa, as Irmãs de São José de Chambery, que, desde 1854, alcançara grande prestígio na administração do Colégio Nossa Senhora do Patrocínio, em Itu. ${ }^{22}$

Apesar de dirigida por religiosas, a instituição permanece subvencionada integralmente pelo governo da Província, e a ele submetido em termos de autoridade e fiscalização. Cabia ao Presidente da Província dar as devidas ordens de matrículas, "atento sempre ao número de vagas estipulado por lei”, e determinar as aulas a serem ministradas. ${ }^{23}$

Segundo os documentos pesquisados, o tipo de educação oferecido às meninas modificou-se pouco desde a fundação do Seminário até os anos 70 - isto é, nos seus quase 50 anos de existência: durante todo esse tempo foi condizente com os costumes de uma sociedade escravocrata, de organização familiar patriarcal, que negava à mulher as condições de desenvolvimento intelectual, e especialmente apropriado aos objetivos de obra assistencial destinada a uma categoria "inferior" de criança - as órfãs, "sem fortuna". No entanto, em sua maioria, as meninas "adotadas pelo Estado" provinham de um segmento social específico, sendo majoritariamente filhas de militares e empregados públicos falecidos, o que parece ter contribuído para as características peculiares assumidas pelo estabelecimento.

Como no caso dos meninos educandos artífices, a instrução das meninas, nas décadas de 70 e 80, também limitava-se ao ensino de rudimentos de leitura, escrita e aritmética, além da aprendizagem das chamadas prendas domésticas e de trabalhos manuais de agulha e linha.

A Congregação de São José era originária da França, e a organização do ensino em todos os estabeleci-

${ }^{22}$ Segundo Borges (1980), “o status de freiras estrangeiras, na época, era ponto positivo e não se lhes questionava a forma de organização, diante dos sucessos já obtidos”; que "o fascínio pela França e por tudo o que lhe estava ligado se constituía em motivo suficiente para ser dada 'carta branca' à nova direção".

${ }^{23}$ A lei de 9 de abril de 1872 fixa o número de 100 órfãs pobres, menores de 10 anos. mentos dirigidos pela Ordem, fossem eles destinados às filhas dos fazendeiros ou às meninas pobres, seguia diretrizes francesas. Nos cursos do Seminário, ministrados pelas próprias religiosas, introduziu-se o estudo da língua francesa e da música vocal e instrumental. Além disso, "a disciplina, o asseio, a segurança de bons princípios morais e religiosos" eram cultivados, segundo os dispositivos legais, como requisitos indispensáveis "ao futuro das filhas da Nação".

Outro aspecto introduzido no funcionamento do Educandário pela Irmandade de São José foi a institucionalização do trabalho doméstico das órfãs, que, aos poucos, iam substituindo os empregados da casa. Destas tarefas - que tinham por objetivo "forçá-las ao hábito e metodização da faina doméstica" - ficavam isentas, no entanto, as pensionistas que pagavam trimestralidade (Borges, 1980, p. 81).

As educandas deveriam deixar o Seminário entre os 15 e os 20 anos, quando eram consideradas "aptas para o trabalho". Nessa ocasião, cediam lugar às de menor idade, necessitadas de "agasalho e ensino". Sobre o futuro das órfãs, cuidava o governo que saíssem do Seminário "pelo casamento ou para o professorado", "destinos mais naturais da mulher". Para elas era providenciado um pequeno pecúlio, destinado a auxiliá-las no início da vida profissional ou a servir como dote e atrair "bons pretendentes ao casamento". A lei de 16 de março de 1847 já considerava também como uma das ocupações destinadas às educandas o serviço doméstico em casas de família. No entanto, tal trabalho era dificultado pela "concorrência" dos escravos. Nas palavras do Presidente da Província, em seu relatório para o ano de 1862: "O trabalho, em minha opinião, jamais avilta, e é, muitas vezes, um título de verdadeira nobreza; mas no caso de que se trata, e tendo em atenção os nossos costumes, é exigir dessas infelizes uma abnegação quase superior às suas forças, ou expô-las, pela comunicação em que vão viver com as escravas, suas concorrentes no serviço, a esquecerem-se da educação que receberam e contaminarem-se pelo exemplo de suas novas companheiras". ${ }^{24}$

\footnotetext{
${ }^{24}$ Por causa das dificuldades presentes no encaminhamento das
} órfãs após a maioridade, em parte originárias na organização da so- 
No século passado, ao lado da enfermeira, o magistério primário consistia "a outra via de acesso respeitável no mercado de trabalho" para uma jovem alfabetizada, solteira e sem posses. Convém lembrar que inicialmente, no Brasil, o ensino das primeiras letras era uma atividade masculina, e, até o início do século XIX, havia uma série de restrições ao acesso das mulheres à escola, inclusive como alunas. Somente em 1826 surge a primeira regulamentação dispondo sobre a educação feminina, "na qual se permitia o acesso da mulher ao nível educacional elementar, mas não aos mais avançados" (Pena, 1981). Na sociedade de então, caracterizada pelos baixos índices de escolarização, o exercício do magistério primário consistia numa profissão de "alto prestígio social" para a mulher sem posses, que lhe permitiria "certa dignidade no seu modo de vida" (Pena, 1981).

Neste sentido, é importante considerar que, ao contrário do que ocorreu com os meninos órfãos asilados no Instituto dos Educandos Artífices e com as meninas internas em estabelecimentos privados, não foi cogitado pelas esferas governamentais utilizar as menores nas atividades industriais nascentes. E, no entanto, o trabalho nas fábricas de tecidos tendia a ser exercido, desde sua fundação, majoritariamente por mulheres. Em 1872, a força de trabalho da indústria têxtil, constituída por um total de 10.256 operários, apresentava um contingente de 9.514 operárias (Canabrava, 1951, p. 271). ${ }^{25}$

ciedade da época que dificultava o ingresso da mulher no mercado de trabalho e, em parte, atribuídas à inadequação do estabelecimento aos objetivos propostos, o relatório presidencial de 1874 propõe a extinção do Seminário: "Nem a verdadeira caridade, nem mesmo a moralidade podem lucrar com este estabelecimento. [...] Durante minha administração e já por muito tempo antes, nenhuma [educanda] saiu para qualquer dos fins daquele estabelecimento. Nem o casamento, nem o magistério, nem qualquer ocupação lícita industrial tem contribuído para provar a utilidade daquele seminário". Um aspecto interessante a considerar: a inexistência de dados relativos ao número de educandas que teriam ingressado na ordem de São José, como religiosas.

${ }^{25}$ Neste período inicial da industrialização, anterior à vigência da imigração subsidiada, a mão-de-obra era recrutada na população pauperizada da cidade, naqueles grupos desempregados que viviam miseravelmente ao redor das cidades do litoral, numa situação análoga à descrita por Marx quando se refere ao exército industrial de reserva. A este respeito ver Pena (1981).
No caso das internas do Seminário, desde o início o objetivo do governo consistiu em aproveitar as mais aptas à profissão no ensino das primeiras letras. Em 1845, não havendo na Província escola que preparasse professores, quer do sexo masculino, quer do feminino, ficara estabelecido que as alunas do Seminário poderiam ser nomeadas professoras, desde que as que fossem seguir o magistério se preparassem com seis meses de antecedência. ${ }^{26}$ Nessa época, além dos misteres manuais, as áreas do ensino estavam limitadas à língua portuguesa - (princípios elementares) - e à aritmética (as quatro operações). No programa de 1861(prescrito pelo art. 2 da lei 34 de 25 de setembro de 1846) encontramos ainda o ensino de prendas domésticas e das seguintes matérias: leitura, escrita, gramática portuguesa e princípios da moral cristã e da doutrina do Estado. "[...] isto era suficiente para que as educandas alcançassem o nível exigido para o magistério de primeiras letras e se constituía no suficiente para a educação feminina" (Borges, 1980, p. 70). Posteriormente aprovou-se uma lei criando uma Escola Normal no seminário, mas foi revogada em 1856, "sem se instalar a escola, mas ali ficou o simulacro". ${ }^{27}$ Novamente, em 1876, visando "assegurar a essas filhas da província uma posição social, independente e honrosa", a Assembléia Provincial cria, na Escola Normal, uma seção para o sexo feminino e a instala no pavimento inferior do Seminário da Glória. No entanto, permaneceu pouco tempo em funcionamento - a seção foi fechada por ato do Presidente da Província em

${ }^{26}$ Segundo o Regulamento de 7 de janeiro de 1845 , a órfã, completando 18 anos e não se casando ou não se empregando como criada, "seria provida na primeira cadeira de primeiras letras para o ensino de meninas que se vagasse na Província, independente de exame estabelecido por lei para tais provimentos". A lei de 7 de maio de 1845 elevou a idade de 18 para 25 anos (Escobar, 1933, p. 158-190).

${ }^{27}$ Em 1846 foi fundada na província uma Escola Normal, destinada só aos homens. Tinha apenas um professor, o Dr. Manuel José Chaves, catedrático de filosofia e moral no Curso Anexo à Faculdade de Direito. Parece que a escola só formou 40 professores até 1866; em 1867 foi suprimida. A baixa freqüência era explicada pelo Inspetor Geral do Ensino, dr. Diogo Mendonça, como conseqüência dos "mesquinhos vencimentos" do magistério, por volta de $300 \$$ a $400 \$$ anuais. Ver Escobar (1933), p. 166. 
1878, deixando de funcionar definitivamente em 1880, quando é reaberta a Escola Normal que, passando a mista, dispensa a existência da seção exclusivamente feminina. A freqüência das moças do Seminário a essa escola mista dependia não só da aprovação dos responsáveis por elas, como também de que estes as acompanhassem às aulas, já que as Irmãs se negavam a fazê-lo. Apesar da insistência do presidente da Província, a diretoria do Seminário não modificou sua decisão.

O jornal A Província de São Paulo, indignado com a conduta das Irmãs, destina um número significativo de seus editoriais de 1880 a questionar a utilidade do estabelecimento e a propor o seu fechamento. ${ }^{28}$ Os editoriais condenam os colégios de irmãs de caridade, quer jesuítas ou lazaristas, pois estes se organizam "segundo um plano que nasce naturalmente da instituição a que se acham filiados pelo espírito da propaganda: são antes de tudo casas de religião". As freiras - mulheres "fanatizadas por sua fé, pela obediência aos seus superiores na hierarquia eclesiástica" - seriam incompetentes para preparar moças para a vida moderna. ${ }^{29}$

O Seminário da Glória, tal como estava organizado, era prejudicial à sociedade paulista: a "caridade" exercida daquela maneira, por conta dos cofres públicos, merecia sério exame; mesmo constituindo-se, conforme argumento presidencial, em remédio contra a prostituição, "salvando centenas de meninas da desonra", nada justificava a utilidade de um estabelecimento que se propunha a educar meninas tendo como "guia a irmã de caridade e por freio a religião". ${ }^{30}$

${ }^{28}$ A PSP, 14/9/1880. Por causa dos entraves colocados pela Irmandade, naquele ano, das 14 jovens interessadas na Escola Normal apenas 3 conseguiram freqüentar as aulas "acompanhadas por pessoas da família que assim requereram". Analisando os dados fornecidos pelos relatórios presidenciais, Borges (1980) observa que em 1886, quinze anos após o início desta segunda fase, saía a última educanda, diretamente para o Magistério Público. Aliás, até esse ano, excluindo-se o de 1882, do qual não há registro conhecido, e o de 1884, cujas sete saídas são sem especificação, "partiram do Seminário 27 professoras públicas, número insignificante se comparado aos 46 dos 10 anos da fase anterior, em que se pese a diferença de situações".

\footnotetext{
${ }^{29}$ A PSP, $10 / 09 / 1880$.

${ }^{30}$ Idem.
}

Vários artigos sobre a necessidade de "elevar o nível de educação da mulher brasileira" são publicados no período. Se a mulher é "julgada incapaz de ter um pensamento sério", isto se dá "porque lhe falta instrução e não por problemas orgânicos". Guardadas as diferenças relativas à condição social, toda mulher - rica ou pobre deveria ser bem educada. Sua educação fazia-se tão ou mais importante que a do homem, por dela depender a formação dos filhos, importante "meio de salvar-se a liberdade e evitar a decadência dos caracteres". ${ }^{31}$

De acordo com o periódico republicano, na sociedade que se anunciava não havia mais lugar para instituições esclerosadas, nas quais incluíam desde o Estado centralizado do Império até internatos como o Seminário da Glória e o Instituto de Educandos Artífices, este último transformado em uma espécie de "depósito de menores". Era hora de reinventar a educação e forjar a nova sociedade.

Nos anos seguintes, as autoridades republicanas agem no sentido de criar instrumentos e saberes necessários à incorporação e ajustamento da crescente população trabalhadora que surge na nova e diferenciada sociedade urbana industrial. Ao lado da difusão de instituições de educação popular (escolas primárias isoladas e rurais e ensino profissional), elas se dispõem a construir instrumentos eficazes de regeneração, de transformação dos indivíduos, tão aperfeiçoados quanto a escola e o quartel.

\section{O snovostempos: onde estão as crianças?}

Em 1918, o então Diretor da Instrução Pública do Estado, Oscar Thompson, constatava que nos $196 \mathrm{mu}$ nicípios do estado funcionavam 176 grupos escolares, 31 escolas reunidas, 1.595 escolas isoladas, além das 358 sustentadas pelas câmaras municipais e das 1.089 particulares, atendendo a 232.621 crianças. Frente a esta realidade, perguntava-se: "Que fizeram as restantes crianças em número de 247.543? Nada. Umas vagaram pelas ruas, outras ficaram em casa, num perfeito ócio,

${ }^{31}$ A PSP, 16/1 e 22/1/1876; A PSP, "Questões Sociais: A educação da mulher", por Damiana Rangel Pestana (esposa de Francisco Rangel Pestana, um dos donos e redator do jornal), 11/12/1877. 
outras foram abusiva e criminosamente introduzidas nas fábricas e outras ainda acompanharam os pais nos serviços da lavoura". 32

O educador Almeida Júnior, em conferência realizada na Sociedade de Medicina e Criminologia de São Paulo, em 1932, afirmava existir na capital do estado, segundo os cálculos da Demografia Sanitária realizados em 1930, 1.070.986 pessoas, sendo que, destas, aproximadamente 59.187 eram crianças de 11, 12 e 13 anos de idade. E argumentava ser este o número de menores "implicitamente abandonados pela lei": "O Estado os despede da escola. A União os afasta da oficina. Um e outro os lançam no grande e sombrio hiato da desocupação". E, como Thompson havia feito catorze anos antes, pergunta-se: "Onde estão eles?".

Apesar das distorções comuns às estatísticas escolares no período, era possível supor - numa projeção otimista - que aproximadamente 30.696 menores cursavam efetivamente, naquele ano, as escolas paulistas. Sobravam, portanto, 28.491, dos quais cerca de mil, entre 12 e 14 anos, encontravam-se trabalhando nas indústrias da cidade. Este era, naturalmente, o número conhecido, o "dos admitidos legalmente no trabalho". Havia aqueles que lá estavam clandestinamente, cuja quantidade era desconhecida, como imprecisas eram as informações sobre as suas condições de trabalho, sobre o tempo da jornada diária - de seis horas, como mandava a lei, ou de oito, nove ou mais horas "como o faz a prática" - e, conseqüentemente, sobre o estado da sua saúde. Segundo Almeida Júnior (1933), a respeito dos menores de mais de 14 anos, a Federação Industrial estimava que só na capital, em 1930, “esse operariado juvenil” alcançaria a totalidade de 150.000 , cálculo que era "evidentemente exagerado". No entanto, considerava o autor, "todos sabem como é preferido o trabalho industrial dos menores, que, sobre ser mais barato, é

${ }^{32}$ Anuário do Ensino do Estado de São Paulo, 1918, p. 25.

${ }^{33}$ Almeida Júnior, A. 1933, p. 25-43. O educador Almeida Júnior, assessor de Sampaio Dória na Diretoria da Instrução Pública, nos anos 20, membro do Liceu de Artes e Ofícios de São Paulo, participou ativamente da criação da Universidade de São Paulo, fazendo parte da comissão que redigiu o projeto desta universidade. Em 1934, ao lado de Dória e F. Azevedo, irá elaborar os estatutos da instituição. exercido por um operariado dócil e relativamente disciplinado". De acordo com Almeida Júnior, estas eram as únicas parcelas conhecidas "com alguma aproximação": as das escolas e a dos admitidos legalmente ao trabalho. As outras continuavam "totalmente ignoradas". No entanto, podiam ser feitas conjecturas sobre o destino das 27.000 crianças restantes. Uma parte delas seria certamente encontrada "nas profissões ambulantes: são vendedores de doces, mensageiros, entregadores de encomendas, carregadores de feira, cambistas de loteria, engraxates e, sobretudo, vendedores de jornais". Entre as meninas prevalecia o emprego doméstico. Muitos dos menores exerciam simultaneamente duas ou mais profissões: "pela manhã vendem jornais; durante o dia, engraxam sapatos; nos intervalos, estendem a mão à caridade".

O autor considerava que "a infância pré-púbere" tinha "acentuado pendor por esse gênero de vida". A vida ambulante seria, para o menor, "menos profissão que brinquedo", apresentando maior conformidade com a psicologia infantil do que o trabalho industrial. ${ }^{34} \mathrm{En}$ tretanto, pesavam sobre esse menor "as circunstâncias físicas das intempéries, a incerteza da alimentação, a promiscuidade, causas da debilidade e moléstia”, e ain-

${ }^{34}$ Discordando das conclusões de um estudo realizado pela Federação Industrial a respeito do trabalho fabril de menores entre 13 e 14 anos, que indicavam não ocorrer perda de saúde ou retardamento na evolução psíquica dos jovens operários, Almeida Júnior (1933) contra argumenta em defesa da proibição do trabalho infantil na indústria: “A fisiologia, a psicologia, a higiene, são justamente, não os únicos, mas os principais acusadores do trabalho de menores, como causa do depauperamento e de violência ao natural desenvolvimento orgânico [...] Por hora, queremos acentuar apenas que é, em nome da saúde infantil que esse trabalho, é condenável, na forma que é efetuado, tenha ou não o menor o seu certificado de estudos primários, seja ele ou não arrimo dos pais, entre ele para a fábrica clandestinamente ou munido de permissão legal [...] A indústria sofreria, se elas fossem impedidas de prestar serviços; sofreriam também as famílias obreiras; sofreríamos todos. Esse argumento não pode ser esquecido. Mas o direito das crianças deve antepor-se aos demais direitos. $\mathrm{O}$ direito de crescer normalmente precisa ser garantido pela lei. $\mathrm{O}$ direito de brincar, é sagrado. Que se procurem outros remédios para o mal das indústrias; que se amparem de outra forma as famílias desafortunadas, mas não à custa da saúde das crianças". 
da as "pavorosas" "condições morais da rua". Apenas "os caracteres privilegiados podiam resistir-lhe à força deturpadora". 35

Pelas suas características, a vida ambulante do menino constituía "o caminho mais curto para a delinqüência"; o emprego doméstico da menina, era "freqüentemente a reta que conduz à prostituição". O autor observa que os vendedores de jornal forneciam "larguíssimo contingente para a deliquência infantil" e que, no período em que trabalhara no Instituto Disciplinar, notara "a freqüente internação de meninos daquela proveniência". A seu ver, a disposição do Código de Menores em proibir as profissões de rua às crianças de idade inferior a 14 anos era "de um platonismo comovedor". As ruas continuavam "coalhadas de menores", de crianças com até menos de 8 anos. "Ao decretar sobre os trabalhos que a criança não deve realizar, esqueceu-se o Estado de organizar as cousas que ela deve fazer para encher o vazio de seu tempo". A lei deixara de deliberar sobre o que era mais urgente, a respeito do que era preciso construir.

Havia, ainda, um último grupo de crianças nesta idade, os "francamente desocupados", vivendo em "semiabandono ou em abandono total": "Dormem às vezes em casa, outras vezes na soleira das portas. Andam ao léu. Da escola, se é que por lá passaram, saíram sem terminar o estudo. Não estão trabalhando em cousa alguma. No triângulo central, na Praça da Sé, no largo de São Bento, nas proximidades do Viaduto, na Rangel Pestana, na cidade inteira topamos com eles. Passam o dia andando e olhando. Comem e dormem à custa de expedientes". E, acrescenta, "daí para a mendicância e a delinqüência quase nada falta".

O Código de Menores recomendava a isenção penal do menor infrator e sua internação em casas de educação. ${ }^{36}$ Mas, elas não existiam na quantidade deseja-

${ }^{35}$ De acordo com o referido autor, nos "grupos de ambulantes" predominavam "certas superioridades", a "dos violentos e a dos viciados": “Um se fez 'leader', é o que fala mais alto e mais rouco. Este conduz, aconselha, inicia. É quem decide e ordena, quem castiga e expulsa. É, na linguagem deles, o 'chefe de chaparia'. O chefe de 'chaparia', é o grande educador da criança de rua”. Entre estes, observa, "avultam os vendedores de jornais” (Almeida Júnior, 1933).

${ }^{36}$ Através do art. 68, o Código de Menores altera o Código Penal de 1890 (art. 27, parágrafo $2^{\circ}$ ), isentando o menor de 14 anos, da: "Os poucos asilos que temos se acham superlotados. Voltam eles [os menores] para a rua, para o mesmo meio, e já tranqüilizados pela experiência do primeiro contato com o aparelho de justiça" (Almeida Júnior, 1933).

O relato de Almeida Júnior é finalizado com apelo comovente às autoridades da época para que sanassem o abandono, o grande "hiato de assistência na vida dos menores", justamente dos que mais precisavam do "amparo social".

A situação social no princípio do século retratada pelo autor apresenta atualidade incontestável. No decurso de todos estes anos, as medidas institucionais destinadas às resolução do problema do menor órfão, abandonado ou delinqüente não sofreram mudanças significativas: asilos e orfanatos para os menores abandonados, institutos disciplinares ou correcionais para os infratores, até a FEBEM de nossos dias, todos plasmados no modelo autoritário da instituição fechada, normatizada segundo o exemplo das corporações militares. As variações ocorrem, historicamente, na forma como as crianças dos segmentos populares são vistas e representadas e nas justificativas ideológicas construídas para explicar sua existência. No entanto, a lógica que articula as diferentes falas nos diferentes tempos da história parece ser coincidente. Mais ou menos autoritárias, elitistas ou preconceituosas, dependendo das necessidades impostas socialmente à incorporação destes setores marginalizados - como as de conter ou minimizar os riscos de conflito e as ameaças à propriedade, que então representavam, ou a do seu aproveitamento como força de trabalho farta e barata - são sempre consensuais quanto à exigência de moralizá-los e cerceá-los do convívio social. O seu uso no processo produtivo é um fim freqüentemente visado, cujo sentido e significado também mudam historicamente com o avanço das relações sociais capitalistas e a expansão da indústria. A concepção do trabalho como instrumento pedagógico moralizador irá, nesta sociedade em construção, combinar-se admiravelmente com os rigores da disciplina fabril, ou seja, com a nova moral da produtividade.

\footnotetext{
"indigitado autor ou cúmplice de fato qualificado crime ou contravenção", de ser submetido a processo penal.
} 
Conforme já se indicou, o único estabelecimento oficial criado no Império e destinado a abrigar menores foi fechado antes mesmo da vigência do regime republicano. Com exceção de alguns poucos institutos particulares, encontrava-se a província destituída de instituições destinadas a suprir esta finalidade. E, no entanto, a situação era considerada bastante grave pelo Chefe de Polícia, Bento Pereira Bueno. ${ }^{37}$ Em seu relatório ao Secretário de Justiça e Segurança Pública, datado de 1896, esta autoridade denunciava a existência de grande número de crianças abandonadas vagando pelas ruas, "maltrapilhas e famintas, esmolando às vezes por conta de outrem, na mais triste degradação", e das que constantemente figuravam em casos policiais "como auxiliares de gatunos ou autores de pequenos furtos". 38

De acordo com estatísticas da época, entre 1900 e 1916, o coeficiente de prisões por dez mil habitantes era distribuído da seguinte forma: “307,32 maiores e 275,14 menores". Os dados mostram que os menores eram responsáveis neste período por " $22 \%$ das desordens, $22 \%$ das vadiagens, $26 \%$ da gatunagem, $27 \%$ dos furtos e roubos, $20 \%$ dos defloramentos e $15 \%$ dos ferimentos". ${ }^{39}$

Diante da situação, e na falta de "escolas e oficinas industriais" que, a seu ver, alcançavam "belos resultados" em outros países, Bento P. Bueno sugeria a internação destes menores "nos estabelecimentos de caridade já existentes, concedendo-lhes o governo subsídios relativos ao número de crianças que lhes fossem confiadas". Acreditava que, desta forma, seria possível ao Estado exercer a "nobre função" de "resgatar do vício e da miséria as crianças que nela nascem ou que para ela deponham". ${ }^{40}$

${ }^{37}$ Bento Pereira Bueno foi chefe de polícia no governo Campos Salles e Secretário do Interior na gestão Rodrigues Alves e durante o governo de Bernardino de Campos (1900 a 1904).

${ }^{38}$ Relatório apresentado ao Secretário dos Negócios da Justiça pelo chefe de polícia Bento Pereira Bueno, em 31 de janeiro de 1896, p. 175. Apud Blanco (1977).

${ }^{39}$ Relatórios apresentados pelo Chefe de Polícia da capital ao Secretário da Justiça e Segurança Pública (1904-1906), apud Santos (1999).

${ }^{40}$ Relatório do Chefe de Polícia da capital, Bento Pereira Bueno, ao Secretário dos Negócios da Justiça, em 31 de janeiro de 1896, p. 175. Apud Blanco (1977).
Em 1902, o governo de Bernardino de Campos cria o Instituto Disciplinar com o objetivo de sanar estas dificuldades. Instalado na capital, no bairro do Tatuapé, e já considerado pelo Secretário da Justiça como uma medida insuficiente "frente às proporções do problema", destinava-se a abrigar menores do sexo masculino, entre 9 e 21 anos, os "pequenos mendigos, vadios, viciosos, abandonados", incluindo-se aqueles condenados, por infração, pelo Código Penal então vigente. Subordinada à Secretaria da Justiça, sob a imediata inspeção do chefe de polícia, a instituição foi instalada com o objetivo específico de promover "a regeneração dos menores criminosos e corrompidos”. Para alcançá-lo, propunha-se segundo seu regulamento interno - a "incutir hábitos de trabalho, a educar e a fornecer instrução literária e profissional, de preferência a agrícola". ${ }^{41}$

Até essa data, de acordo com indicações fornecidas pela imprensa ou contidas nos relatórios dos Secretários do Interior, é provável que os "delinqüentes de menor idade", quando condenados, fossem colocados em prisões junto aos "criminosos comuns". ${ }^{42}$ Mesmo depois da instalação do Instituto Disciplinar estas ocorrências deviam ser freqüentes, pois o estabelecimento só rece-

${ }^{41}$ Regulamento do Instituto Disciplinar, Cap. 1, art. $1^{\text {o }}$, p. 90, conforme o Decreto ${ }^{\circ} 1.079$, de 3 de dezembro de 1902, para execução da lei n ${ }^{\circ} 844$, de 10 de outubro de 1902.

${ }^{42}$ A lei $\mathrm{n}^{\circ} 44$, de 10 de outubro de 1902, autoriza o governo do Estado a fundar uma colônia "destinada à correção, pelo trabalho, dos vadios e vagabundos" e "para internação dos condenados que, pelo seu comportamento estavam destinados ao livramento condicional". Instalada por volta de 1907 e 1908, na Ilha dos Porcos, a uma légua de Ubatuba, a planta desta prisão agrícola foi elaborada por Francisco de Paula Ramos de Azevedo. De acordo com Jorge Tibiriçá, a Colônia Correcional era o primeiro lugar no Brasil onde seriam experimentadas as "salutares disposições" do Código Penal que permitiam "a transformação da pena de prisão celular em internação em penitenciárias agrícolas e, em seguida, a concessão do livramento condicional". O livramento condicional foi concedido a um sentenciado, pela primeira vez no Estado de São Paulo, no ano de 1918. Em 1905 foi autorizada a construção de uma nova penitenciária na capital, servida até aquela data por duas instituições penais: a velha Penitenciária do Estado e a Cadeia Pública, insuficientes para o número de ocorrências. Parece, no entanto, que só em 1920 será inaugurada a nova penitenciária, localizada no Carandiru. 
bia meninos da capital. Em 1902, quando o número de menores presos em todo o estado atingia a cifra de 1.650, numa população carcerária de 12.518 pessoas, o Instituto só apresentava disponibilidade para 50 crianças. ${ }^{43}$ No ano de 1907, o Presidente da Província comunica ao Congresso a realização de uma reforma no edifício, destinada a aumentá-lo para que pudesse receber a internação de 100 menores. $^{44}$

Nesta mesma data, havia 9.361 presos no estado e, destes, 1.565 eram menores de idade. No ano seguinte, este total havia aumentado para 2.047 crianças, levando o governo a providenciar a criação, nas localidades do interior, "de mais quatro institutos idênticos ao do Tatuapé". Além disso, Albuquerque Lins reitera ao legislativo sua proposta de completar o desenvolvimento do "sistema repressivo e preventivo do Estado" através da criação de institutos industriais "destinados a recolher, afeiçoar à vida moral pelo trabalho, pela escola e por um regime disciplinar, os menores de 21 anos que ainda não são criminosos, e que ainda não são mesmo viciosos, mas que, não dispondo de proteção paternal, ou de auxílio tutelar, constituem os moralmente abandonados, os candidatos ao delito ou, pelo menos, os incapazes do trabalho e da virtude, destinados a pejarem numa sociedade, na qual serão elementos inúteis, quando não forem prejudiciais". Recomendava que esta obra de "prevenção tutelar", caracterizada como mais do que assistencial e menos do que repressiva, fosse confiada a particulares ou a associações, reservando-se ao Estado a fiscalização e os auxílios diretos e indiretos. Acreditava que, desta forma, os jovens, ao terminarem a minoridade, não encontrariam dificuldade de se colocar em algum emprego, "porque os institutos profissionais não têm criminosos, nem viciosos". Eles continuariam a

${ }^{43}$ Mensagem Enviada ao Congresso Legislativo, a 14 de julho de 1907, pelo Presidente do Estado de São Paulo, Dr. Jorge Tibiriçá, p. 342-343. Os dados referentes à população carcerária e ao número de menores presos na capital foram retirados dos Relatórios da Secretaria de Estado dos Negócios da Justiça e da Segurança Pública e dos Chefes de Polícia do Estado de São Paulo, anos: 1900-1915, cit. por Blanco 1977, p. 219.

${ }^{44}$ Mensagem... pelo Presidente do Estado, dr. M. S. de Albuquerque Lins, 1917, p. 292-293. receber “abrigo no Instituto Disciplinar”. Com esta providência, o Presidente do Estado procurava resolver outro sério embaraço: "a colocação dos desamparados". Era costume os juízes de órfãos tentarem intervir "dando esses homens a soldados e famílias de reconhecida moralidade". No entanto, encontravam dificuldades pois, "em regra, as famílias, por óbvios motivos, não estimam tal incumbência". ${ }^{45}$

Apesar de todas as recomendações, não surgiram os tais institutos industriais. É, no entanto, bastante provável que algumas instituições particulares, devidamente conveniadas com o Estado, asilassem os menores. Quanto aos institutos disciplinares a serem instalados no interior, só sete anos depois, em 1914, o relatório presidencial menciona a conclusão das obras dos edifícios. Em 1916, entretanto, ainda não estavam em funcionamento, e a previsão era inaugurar apenas uma destas instituições na cidade de Moji-Mirim. Mais tarde, é instalado em Taubaté, um Instituto Correcional e, até o início da década de 30, funcionarão as duas instituições oficiais para menores: uma na capital e outra, no interior. ${ }^{46}$

\section{O Instituto D isciplinar}

O Regimento Interno destas instituições não sofreu modificações ao longo dos anos. Foram realizadas apenas adaptações no currículo escolar, com a introdução de alguns conteúdos profissionalizantes e a organização de oficinas para a parte prática.

Conforme determinavam as normas regimentares, assim que chegava ao Instituto, o menor - transformado pela prática penal em objeto de saber e de intervenções era submetido a um "interrogatório", "sigiloso", que permanecia em poder do diretor do estabelecimento. A seguir, passava pelos exames médicos, sendo depois fotografado "para ulterior verificação de identidade". Por fim, finalizada a primeira fase do processo de observação permanente do interno, no qual a biografia constituía elemento subsidiário importante à aplicação da téc-

${ }^{45}$ Mensagem... pelo Presidente do Estado, dr. M. S. de Albuquerque Lins, 1917, p. 292-293.

${ }^{46}$ Mensagem... pelo Presidente do Estado, dr. Altino Arantes, 1916, p. $718-719$. 
nica de reeducação que então se iniciava, o menino era conduzido à sua respectiva classe. ${ }^{47}$ Determinava o artigo 10 do Regimento que, na instrução e nos trabalhos em que fossem aproveitados, o diretor deveria dividir os menores "de cada seção" - a priori classificados em classes de acordo com o grau de periculosidade e o tipo de penalidade recebida -, "conforme a idade, robustez física e aptidão de cada um".

Os meninos recebiam, diariamente, instrução primária, compreendendo as seguintes matérias: leitura, princípios de gramática, escrita e caligrafia; cálculo aritmético sobre números inteiros, frações e sistema métrico decimal; rudimentos de ciências físicas, químicas e naturais, aplicáveis [...] agricultura; desenho à mão livre. Em 1909, o governo cria uma escola noturna no estabelecimento, sendo nomeado para o cargo o professor Antônio de Almeida Júnior. Constavam também da programação aulas de música vocal e instrumental regidas por professor contratado pelo governo estadual "por prazo nunca maior de dois anos". ${ }^{48}$ Estas aulas,

${ }^{47}$ Para Michel Foucault (1977), “o panóptico penitenciário, também um sistema de documentação individualizante e permanente". Trata-se de "fazer da prisão um local de constituição de um saber que deve servir de princípio regulador para o exercício da prática penitenciária. A prisão não tem só que conhecer a decisão dos juízes e aplicá-las em função dos regulamentos estabelecidos: ela tem que coletar permanentemente do detento um saber que permitirá transformar a medida penal em uma operação penitenciária; que fará da pena tornada necessária pela infração uma modificação do detento, útil para a sociedade".

${ }^{48}$ Regulamento do Instituto Disciplinar, cap. II, do Regimento Interno, arts. 13 a 24 . O pessoal do Instituto compunha-se de: diretor, um escrivão, um mestre de cultura, um professor e vigilantes (sem que a quantidade fosse especificada). Conforme o art. 47 do Regulamento, o diretor, o escrivão e o professor - diplomado pelas escolas normais ou complementares do Estado - eram nomeados e demitidos por decreto do presidente do Estado, sob proposta do chefe de polícia. Os vigilantes eram contratados pelo diretor, com aprovação do chefe de polícia, "por prazo nunca maior de um ano" (art. 48). O mestre de cultura estava encarregado dos "trabalhos de agricultura e congêneres" (art. 56). O diretor e os vigilantes residiam no estabelecimento (art. 57). Em 1902, os vencimentos do diretor eram de 6:000\$000; do mestre de cultura, 4:200\$000; do professor e do escrivão, 3:500\$000 cada um. assim como as de canto coral e ginástica, juntamente com os exercícios militares, realizavam-se nos domingos e feriados. Além das atividades escolares, os meninos eram "empregados na agricultura, sobretudo, na horticultura, floricultura, arboricultura [...] na criação do gado, de aves domésticas e nos demais trabalhos congêneres". Estava previsto que o diretor poderia, com a devida autorização do governo, criar as oficinas que considerasse necessárias para o ensino das artes e ofícios, "tendo em vista as vantagens econômicas do estabelecimento e as conveniências do aproveitamento dos alunos".

A esse respeito, mesmo considerando que o estabelecimento vinha prestando bons serviços, "já tendo salvado indivíduos que vão ser úteis à sociedade a que foram restituídos", o Secretário da Justiça admite que a instituição requer uma "reforma na orientação de seus trabalhos disciplinares". Visando adequar o ensino dos ofícios ao mercado de trabalho urbano, Sampaio Vidal solicita ao Congresso Legislativo as verbas necessárias para "instalações industriais propriamente ditas, oficinas mecânicas, de marcenaria, sapataria e outras". ${ }^{49}$

Em 1914, o Presidente Carlos Augusto Guimarães comunica a instalação definitiva das oficinas do Instituto Disciplinar da Capital. Com "manifesta economia para os cofres públicos", achavam-se em funcionamento e atendendo as encomendas feitas, as seções de mecânica, carpintaria, funilaria, fundição e colchoaria. ${ }^{50}$ No ano seguinte, são efetuadas reformas para melhoria e ampliação do velho e insalubre prédio em que funcionava a instituição,

${ }^{49}$ Relatório apresentado ao Dr. Francisco de Paula Rodrigues Alves, Presidente do Estado, pelo Secretário da Justiça e Segurança Pública, Raphael A. Sampaio Vidal, 1913, p. 29, apud Blanco (1977), p. 130. A defesa do Secretário é realizada nos seguintes termos: "Atualmente o serviço agrícola é o único a que estão sujeitos os internados. Não parece que esse trabalho de agricultura possa preencher os fins colimados por esta instituição. Com efeito, quase todos os internados são, como se sabe, meninos de cidade. Aprendem no Instituto a plantar legumes, cereais, etc. Saem dali, a bem dizer, sem ofício algum, porque voltam para a cidade e assim continuam sem profissão que não adquiriram durante a internação. Seria curioso mesmo saber quantos têm procurado a lavoura. Talvez nenhum".

${ }^{50}$ Mensagem... pelo Presidente do Estado, Carlos Augusto Pereira Guimarães, 1914, p. 614. 
localizado na Avenida Celso Garcia, no Brás. Nesta oportunidade, as oficinas serão também reorganizadas.

Segundo a reportagem publicada pelo jornal $O E s$ tado de S. Paulo, por ocasião da festa inaugural das novas instalações do Instituto, em novembro de 1915, as oficinas estavam "perfeitamente montadas, fazendo até lembrar as dos nossos melhores estabelecimentos particulares [...]" ${ }^{51}$ O Secretário da Justiça e da Segurança Pública, Eloy Chaves, em entrevista reproduzida neste mesmo artigo, afirma que a nova reforma fora realizada nas oficinas com o objetivo de completar sua instalação, que era, inicialmente, de "proporções demasiadamente pequenas", apenas "duas serras para madeiras e 5 mecânicas". Foram criadas, então, três divisões no Instituto. Uma agrícola, onde se "ensinaria o trabalho moderno com a variedade de suas máquinas". Outra, mecânica, "em oficinas completas e com os mais aperfeiçoados maquinismos", dividida, por sua vez, em "diversas seções": serraria, marcenaria, carpintaria, folhearia, mecânica, fundição de ferro e bronze, e modelagem. Quanto à fundição - afirmava o Secretário - "muito deve o Estado à Companhia Paulista e ao seu ilustre inspetor geral, Dr. Francisco Monlevade”, por intermédio de quem havia obtido da Companhia Paulista "um magnífico forno inglês para a fundição de ferro, de grande capacidade e valor nunca inferior a dez contos de réis". ${ }^{52}$ Finalmen-

${ }^{51}$ O ESP, Instituto Disciplinar, 2 de novembro de 1915, p. 2.

${ }^{52} \mathrm{O}$ "namoro" das companhias ferroviárias com a Secretaria da Justiça e da Segurança Pública não data desta época. Desde o início de suas atividades, a Cia. Paulista, por exemplo, através de alguma espécie de acordo ou troca de favores com o governo estadual, empregava presidiários como mão-de-obra na conservação e implantação de trilhos. Entre 1918 e 1920, o governo do estado também vai utilizar presos na construção da estrada de rodagem entre São Paulo e Jundiaí. Para evitar “um longo percurso diário”, foram construídos dois acampamentos para moradia provisória dos 120 sentenciados requisitados para o trabalho. Segundo a mensagem presidencial de 1919, o trabalho era "dirigido por oficiais da Força Pública, sob inspeção da Diretoria da Penitenciária". Os sentenciados "trabalhavam por turmas, guiados, na parte disciplinar, por um guarda civil, e na técnica, pelo mestre de turma, escolhido para esse mister dentre os sentenciados que melhor comportamento e mais aptidão tenham demonstrado no serviço". Mensagem... pelo Presidente do Estado, Dr. Altino Arantes, 14/7/1918, p. 3.653. te, a terceira divisão compreenderia o ensino da pecuária, para o que já existia no estabelecimento "um bom começo de criação". A oficina a auferir maiores receitas era a colchoaria. Com ela "o Estado economizava mais de quarenta contos por ano". Todos os colchões necessários às repartições públicas eram fabricados no Instituto. Além disso, o estabelecimento produzia "diversas obras" para a Secretaria da Justiça, sendo que "todas as esquadrias para o $2^{\circ}$ batalhão e para o Instituto Correcional de Taubaté" tinham sido feitas lá. O Secretário considerava, portanto, a possibilidade da instituição vir a se auto-sustentar.

O produto do trabalho executado no Instituto era, por disposição regimental, dividido em duas partes, uma das quais constituía "renda do Estado", sendo a outra "distribuída proporcionalmente entre os menores, como pecúlio, quando saírem do estabelecimento". Até lá, a quantia mensalmente recolhida seria depositada na Caixa Econômica, "em caderneta especial para cada um". ${ }^{53}$

Além de freqüentarem as aulas primárias e trabalharem nas oficinas, os menores eram empregados "nos serviços de lavanderia e cozinha do estabelecimento". Ou seja, a eles cumpria realizar todos os serviços domésticos, não só como medida de economia mas, muito provavelmente, como mais um recurso disciplinar para a reeducação dos delinqüentes. Na constituição do novo sujeito moral, além do aprendizado deste ou daquele ofício, era essencial "o aprendizado da própria virtude do trabalho" (Foucault, 1984, p.133).

A respeito do funcionamento das instituições penais, convém assinalar que, assim como é impossível confundir a prisão - no caso, o reformatório - com uma oficina, o trabalho penal não pode ser visto como força de trabalho "livremente" cedida. A utilidade do trabalho penal não é o lucro e nem mesmo a formação de uma habilidade útil, "mas a constituição de uma relação de poder, [...] de um esquema de submissão individual e de seu ajustamento a um aparelho de produção”. O salário, nessa perspectiva, é apenas um artifício que, além de propiciar a aquisição do hábito e do amor ao trabalho, do "sentido da propriedade", permite avaliar quantitati-

${ }^{53}$ Regulamento do Instituto Disciplinar, Cap. IV, Disposições Gerais, art. 59, p. 96. 
vamente o indivíduo, os progressos de sua regeneração (Foucault, 1977, p. 213-223). Portanto, instituições como o Instituto Disciplinar apresentam muito mais um caráter profilático, corretivo, do que profissional, e apenas secundária e indiretamente chegaram a contribuir para a constituição de um mercado interno de mão-de-obra qualificada. Para isso foram criadas, nos primeiros anos da República, institutos de ensino técnico-profissional, que tinham por objetivo atingir uma população específica, os filhos de operários, aqueles que iriam "seguir a profissão de seus pais" e que constituíam "uma fonte de inesgotável atividade e energia" para o Estado. ${ }^{54}$

Com o objetivo de controlar o comportamento dos internos, o poder disciplinar organiza um sistema de corretivos que incluem, além dos mecanismos ajustadores punitivos, os compensatórios, voltados para a gratificação dos indivíduos. Desse modo, o regulamento previa como recompensas autorizadas "a inscrição no quadro de honra; os lugares de honra na mesa; o suprimento de frutas; os bons pontos; as insígnias de distinção; os empregos de confiança; os passeios especiais; os elogios em particular ou em público; os prêmios de qualquer natureza ou em dinheiro; as cadernetas da Caixa Econômica". Por sua vez, as punições admitidas incluíam: "advertência ou repreensão, em particular ou em classe; a privação do recreio; os maus pontos, que determinam a perda dos bons anteriormente conquistados; o isolamento durante as refeições, em virtude do qual o aluno castigado come numa mesa à parte, e às mesmas horas que os outros; a perda definitiva ou temporária das insígnias de distinção e dos empregos de confiança; a célula clara com trabalho; a célula escura, mas somente para as faltas de extrema gravidade".

A aplicação das sanções implica a obediência ou a quebra das regras institucionais, através das quais as atitudes dos menores são medidas, quantificadas, julgadas e hierarquizadas. Uma espécie de "contabilidade penal”, atualizada quotidianamente, permite realizar a avaliação de cada um. As punições e as recompensas, em concordância com os novos tempos e a nova concepção pedagógica, não incluem o castigo físico, utilizan-

${ }^{54}$ Relatório ao Presidente do Estado de São Paulo, pelo Secretário dos Negócios do Interior e Instrução Pública, 1912, p. 65. do-se de outros processos sutis, cuja violência, mais ou menos explícita, funda-se na emulação, nas pequenas humilhações e no recurso da prisão celular. ${ }^{55} \mathrm{~A}$ "positividade" destas práticas vigentes nas "instituições totais" consiste em contribuir para a eliminação da identidade pessoal de cada interno, da sua individualidade, de forma a padronizar, a homogeneizar os indivíduos, conformando-os ao mesmo padrão moral de submissão e docilidade ao poder; e, ao mesmo tempo, diferenciá-los e hierarquizá-los segundo seus comportamentos e aptidões, de acordo com o uso que se espera fazer deles quando deixarem a instituição. ${ }^{56}$

A lógica inerente ao exercício do poder disciplinar privilegia a vigilância como instrumento mais eficaz e produtivo que a punição. Neste sentido, as normas que dispõem sobre o funcionamento do Instituto constróem uma rede de relações que cercam os menores por todos os lados, permitindo vigiá-los continuamente. O controle sobre o seu comportamento estende-se, repressivamente, sobre a maneira de ser e de falar, sobre a forma de usar o tempo, o corpo e a sexualidade. ${ }^{57} \mathrm{O}$ controle

${ }^{55}$ Almeida Júnior (1933, p. 34), afirmando ser o vício do fumo responsável por $50 \%$ dos delitos disciplinares praticados nas escolas pelos adolescentes, comenta uma passagem, presenciada por ele no recolhimento de menores, ilustrativa de sua rigidez disciplinar: "Vimos, há muitos anos atrás, sob a antiga e defeituosa organização do Instituto Disciplinar, um menor desse estabelecimento, no dia em que concluíra a pena de 15 dias de solitária, pelo delito do fumo: estava magro, pálido, abatido. Da nossa parte, conselhos e exortações. No dia seguinte, ao voltarmos ao Instituto, demos outra vez pela sua ausência: estava de novo na solitária, por mais 15 dias, pelo mesmo delito". A esse respeito, Foucault (1977, p. 212) observa que "o isolamento dos condenados garante que se possa exercer sobre eles, com o máximo de intensidade, um poder que não pode ser abalado por nenhuma outra influência; a solidão, a condição primeira da submissão total [...] O isolamento assegura o encontro do detento a sós com o poder que se exerce sobre ele".

${ }^{56}$ Sobre as instituições totais, ver Goffman (1974). A respeito da positividade do poder disciplinar, consultar Foucault (1984).

${ }^{57} \mathrm{O}$ aluno deveria zelar por sua higiene corporal, pelas boas condições de seu vestuário (recebendo prêmio em dinheiro se o conseguisse) e pelos bens do Instituto, por cujos danos era responsabilizado, sendo descontada de seu pecúlio a importância correspondente ao prejuízo produzido. Era proibido aos menores o uso do fumo, do 
atinge também os familiares e amigos dos internos. As visitas, permitidas aos finais de semana, ocorriam na presença do diretor ou de "um empregado do Instituto", sendo proibido aos visitantes dar dinheiro ou quaisquer objetos aos menores. Estes objetos, guardados pelo escrivão mediante recibo, eram entregues posteriormente conforme determinação do diretor. O envio e recebimento da correspondência era também regulado: os menores só podiam se corresponder com os parentes e tutores, sendo-lhes proibido "empregar palavras ou frases convencionais, escrever em linguagem menos respeitosa, e tratar de assuntos que não digam respeito a eles e aos seus parentes e tutores". Enfim, os internos eram proibidos de receber ou dirigir cartas ou "escritos de qualquer natureza", sem que antes o diretor os lesse e aprovasse. Os livros que compunham a biblioteca do estabelecimento, assim como toda leitura permitida, eram aqueles considerados "compatíveis com a educação moral e intelectual dos alunos".

A vigilância era exercida pelo diretor e por funcionários especialmente contratados para este fim. No entanto, fazia parte das atividades quotidianas da vida institucional a montagem, entre os menores, de uma fiscalização recíproca e hierarquizada. Tal prática estava definida no Regimento nos seguintes termos: "cabe aos mais distintos da turma, conforme a designação do diretor, o encargo de vigiar a conduta de seus companheiros, de admoestá-los, de transmitir-lhes as ordens ou instruções da autoridade superior, e de levar ao conhecimento desta as faltas cometidas para a necessária repressão". ${ }^{58}$

vinho ou de outra bebida alcoólica. A alimentação poderia ser melhorada nos dias autorizadas pelo diretor - o que induz a pensar na sua utilização como mais um dos mecanismos de controle instaurados. Durante o período de férias - trinta dias por ano, de 15 de dezembro a 15 de janeiro - o menor ficava dispensado dos trabalhos escolares, sendo diminuídos os trabalhos de agricultura, de oficina e os demais serviços - dependendo da "conduta de cada um".

${ }^{58}$ A "observação hierarquizada" completa-se com a intervenção do poder judiciário, o qual - através de dois promotores públicos e do curador geral dos órfãos - vai vigiar os vigilantes, ou seja, o diretor e seus subordinados. A Inspeção no Instituto Disciplinar era feita mensalmente, quando as autoridades citadas elaboravam um "relatório reservado" ao Governo, informando-o sobre tudo o que observavam (art. 62 das “Disposições Gerais”, do Regulamento Interno).
No final de cada ano, realizava-se uma festa no Instituto Disciplinar, quando - perante as autoridades e demais convidados - os alunos participavam "em exercícios militares, de ginástica, de canto, e nas diversões que o diretor indicasse". Na mesma ocasião, dava-se a cerimônia especial de entrega dos prêmios aos meninos que haviam se distinguido pelo comportamento e nas atividades escolares. Tais festejos assumiam um significado simbólico especial, o de reafirmar a alcance dos objetivos colimados, ou seja, a conversão moral do menor vicioso e delinqüente.

Em 1916, o Presidente do Estado, Altino Arantes, relata ao Congresso Legislativo que "a repressão à vadiagem", canalizando para o Instituto Disciplinar e Correcional "um grande número de desocupados", havia feito "diminuir consideravelmente do quadro dos delitos os furtos e os assaltos à propriedade". Os bons resultados alcançados por estabelecimentos desta natureza justificavam todos os sacrifícios empregados na sua criação e manutenção: "o pequeno delinqüente, o pequeno desocupado, removidos [...] para um meio de trabalho e moralidade, quase sempre se regeneram. Forças perdidas que eram para a sociedade, para ela voltam revigoradas e sãs". 59

No entanto, completava, se existiam no estado instituições para os menores do sexo masculino, nada havia sido feito "para as menores vadias e delinqüentes". Para sanar esta "falha sensível" que "não se coadunava com o progresso de São Paulo", propunha que o governo realizasse acordo com algum dos recolhimentos para meninas já existentes na cidade, o qual, "median-

${ }^{59} \mathrm{De}$ acordo com os dados fornecidos por Altino Arantes em sua Mensagem ao Congresso, em 1919, durante o ano anterior haviam entrado no Instituto Disciplinar 83 menores, dos quais 76 brasileiros e 7 estrangeiros, sendo 23 maiores e 60 menores de 11 anos. Neste período, o pessoal docente e administrativo compunha-se do diretor, dr. Everardo Valim Pereira de Souza; 4 professores, Paulo Carezzato, Antônio de Almeida Júnior, Caetano Carezzato, com uma vaga a ser preenchida; um Ajudante do Diretor, Alfredo Maragliano dois mestres de cultura, Pedro Francisco Gelas e Joaquim B. Monteiro de Moraes; um guarda-livros-almoxarife, Francisco M. de Araripe Sucupira; um médico, um dentista, um enfermeiro e um guarda-principal. Anuário do Ensino do Estado de São Paulo, 1919, p. 288. 
te módica remuneração pecuniária", recebesse como internas as menores enviadas pelas autoridades competentes. Com esta finalidade, foi realizado um contrato entre o Governo Estadual e o Asilo do "Bom Pastor", instituição privada subvencionada pelo estado, destinada - desde então - " à regeneração de menores vadias, delinqüentes ou corruptas". ${ }^{60}$ O Governo de São Paulo, entretanto, não organizou, no período, nenhuma instituição especial para o atendimento destes casos. Até o final da década de 20, continuou a manter um único estabelecimento voltado para o asilo e educação de menores órfãs e abandonadas: o Seminário das Educandas.

\section{O Seminário das Educandas}

O Governo da República empreenderá apenas algumas ligeiras alterações na organização e funcionamento do Seminário da Glória ou "das Educandas", como então passará a ser denominado. O estabelecimento, destinado ao recolhimento de "meninas órfãs e desprovidas de recursos", continuará sob a direção e ensino de religiosas da Irmandade de São José, que, para isso, recebiam uma dotação anual do estado.

Em 1896, o Secretário do Interior, Alfredo Pujol, considera a necessidade de uma urgente reforma naquela instituição "que a República encontrou incorporada às tradições da antiga província". Nesse sentido, esperava o "voto criterioso" do Senado estadual referendando o projeto apresentado na Câmara dos Deputados por Júlio Mesquita, propondo converter o Seminário em escola profissional para formar professoras. Este era o "maior serviço" a ser prestado pelo Estado às asiladas, "desviando-as das profissões inferiores para uma nobi-

${ }^{60}$ Nos documentos utilizados não há maiores referências ao Asilo do Bom Pastor. No entanto, na listagem dos estabelecimentos de ensino particular que funcionaram na Capital em 1916, o Asilo é citado como subvencionado pelo estado, atendendo a 168 alunos. Em 1923, o Asilo recebia 12:000\$000 do Estado e 10:000\$000 do município de São Paulo, quantia bem menor que a destinada ao Liceu do "Sagrado Coração de Jesus" ou às Escolas Primárias "Sete de Setembro", da Maçonaria: respectivamente 20:000\$000 e 24:000\$000 do estado; 8:000\$000 e 30:000\$000 do município. Relatório da Secretaria dos Negócios do Interior, 1922-23, p. 55. líssima missão, que havia de ser no futuro, o privilégio da mulher". ${ }^{61}$

O projeto, que propunha a criação de dois cursos na casa das educandas, um preliminar e outro complementar, não foi aprovado. Sua tramitação, bastante acidentada, é publicada na íntegra em $O$ Estado de São Paulo. A simples proposta de reformulação acabou por gerar uma acirrada polêmica que dividiu os deputados, levando-os a se posicionar em campos políticos diferentes, conforme a aceitassem ou repudiassem. Os adversários do projeto, liderados pelo deputado Francisco Malta, poderoso fazendeiro da região nova do oeste paulista, próxima de Ribeirão Preto, argumentavam que o projeto vinha "destruir" um asilo da "infância desvalida", "uma relíquia de um passado honroso", que "assinala os sentimentos caritativos do povo paulista". Se, desde "o antigo regime", o Seminário das Educandas "merecera a atenção de todos os governos", com a República, "apesar da separação da igreja do Estado", a mesma atenção fora dispensada ao estabelecimento. O Seminário "era uma destas instituições identificadas com a nossa civilização" e, portanto, contra a qual nunca se poderia atentar. Sugeriam, como contraproposta, que o asilo permanecesse tal qual estava organizado, sob orientação das irmãs de São José, pois, conforme a nova lei, de 1892, dispondo sobre as bases do ensino público no estado, as alunas daquele estabelecimento poderiam ser aproveitadas para professoras das escolas preliminares, sem a necessidade de reformas no funcionamento da instituição. Definindo-se como politicamente "conservador", Francisco Malta conclui tais argumentos afirmando representar "o verdadeiro elemento reformador da sociedade", pois "não se deve levar as reformas além daquilo que é oportuno, daquilo que é conveniente, sob pena de arregarmos inteiramente as melhores instituições criadas no passado". E advertia: "Devemos ser reformadores, mas não demolidores". ${ }^{62}$

${ }^{61}$ Relatório apresentado ao Sr. Dr. Presidente do Estado de São Paulo pelo Secretário dos Negócios do Interior e Instrução Pública, Dr. Alfredo Pujol, em 10/03/1896, p. 61. Nessa época, Júlio Mesquita já era o proprietário do jornal $O$ Estado de S. Paulo.

${ }^{62} O$ ESP, Congresso do Estado, 24/5/1895, p.1-2. Apoiavam o projeto $\mathrm{n}^{\mathrm{o}} 29$, de 1895 , apresentado por Júlio Mesquita, os deputados Rangel Júnior, Cardoso de Almeida, Paulo Novaes e Pereira de Queiroz. 
O deputado Pereira de Queiroz defendia a reformulação, considerando que desde 1870, quando para lá foram as freiras, o Seminário limitava-se a ser "uma casa de reclusão". Cardoso de Almeida, mais comedido, procurava garantir a aprovação do projeto indicando que a reforma não pretendia prejudicar o estabelecimento nem retirar sua direção das mãos das religiosas. Seu objetivo era completar o quadro docente lá existente, de acordo com as necessidades requeridas pelos dois cursos a serem implementados, com a nomeação de novos professores pelo Estado. Segundo este parlamentar, as queixas contra a falta de professoras para a regência das escolas preliminares criadas eram freqüentes e o projeto vinha justamente "atender a estas queixas e ao mesmo tempo amparar as moças ali recolhidas, a fim de que deste estabelecimento não saiam simplesmente damas de companhia, mas também professoras aptas para a regência de cadeiras preliminares”. Propunha, ainda, que, uma vez concluído o curso complementar, as formandas fizessem "um ano de prática de ensino em qualquer escola preliminar", adquirindo, em conseqüência, o direito de serem providas nos lugares das professoras preliminares "com as mesmas regalias que as diplomadas pela Escola Normal". ${ }^{63}$ De fato, como assinalavam os parlamentares do projeto Júlio Mesquita, existia grande desproporção entre o número de cadeiras criadas e as realmente existentes. Em 1897, havia 2.397 cadeiras criadas para 1.335 providas e, destas, apenas 320 as preliminares, 371 as intermediárias e 644 as provisórias. ${ }^{64}$ No entanto, o pro-

${ }^{63}$ De acordo como a lei $n^{\circ} 88$, de 1892 , que reformou o ensino público no estado, nas escolas providas classificadas como preliminares, os professores em exercício eram os titulados pela Escola Normal; nas escolas classificadas como intermediárias, os professores não titulados mas considerados habilitados por lei; e, nas provisórias, os professores interinos examinados perante os inspetores de distrito. Sobre isso, ver Antunha, 1976, p. 64.

${ }^{64}$ Sob a vigência da lei de 1892, alterada em 1893, a Escola Normal tornou-se mais seletiva, com a dilatação do curso para quatro anos e o alargamento de seu plano de estudos. Segundo opiniões da época, estas mudanças contribuíram "para a limitada freqüência que a escola veio a ter nos primeiros anos posteriores à reforma”, e, desta maneira, "para a considerável penetração no magistério de elementos jeto foi rejeitado com a alegação de que "a organização projetada além de acarretar aumento de despesa, poderia sacrificar o pessoal administrativo [...] à testa do estabelecimento". ${ }^{65}$

Ao contrário do que ocorria com os menores órfãos e abandonados, meninas e meninos asilados nas instituições do estado ou nas casas de caridade, freqüentemente requisitados para operar as tarefas menos qualificadas nas oficinas têxteis, não foram encontradas referências - também neste primeiro período republicano - a respeito da utilização das internas do Seminário da Glória em atividades fabris. ${ }^{66}$

Talvez a explicação resida no fato de estas meninas terem sido sempre requisitadas pelo Estado - fosse ele monárquico ou republicano - para suprir a ausência de professoras nas escolas da capital e até do interior. Alarico Silveira, quando Secretário do Interior, faz algumas considerações em seu relatório ao governo, referente ao ano de 1922, que parecem confirmar estas suposições. Segundo ele: “Antigamente, muitas meninas se formaram para o ensino primário. Quando faltavam professoras públicas, o governo mandava examinar as educandas; muitas dentre elas foram nomeadas para preencher cadeiras vagas. No intervalo de 4 ou 5 anos, foram escolhidas: uma para professora da Escola Modelo, anexa à Escola Normal desta Capital, 8 providas em cadeiras de cidades, e 24 para o interior, ainda 55 apro-

leigos, interinamente providos em escolas "provisórias"”. Tanuri, 1979, p.100.

${ }^{65}$ Relatório apresentado ao Sr. Presidente do Estado de São Paulo pelo Secretário dos Negócios do Interior e Instrução Pública, Antônio Dino da Costa Bueno, em 15/3/1897.

${ }^{66}$ Através de dados fornecidos pelo Departamento Estadual do Trabalho, observa-se que, em 1912, a participação da força de trabalho feminina nas fábricas de tecidos alcançava a cifra de $71,75 \%$ - ou seja - 3.642 mulheres (2.302 adultas e 1.340 menores de 16 anos) num total de 5.076 trabalhadores. O recenseamento realizado em 247 indústrias têxteis, em 1920, aponta para a presença de 17.747 mulheres, equivalente a 50,96\% dos 34.825 trabalhadores deste ramo industrial. O mesmo censo indicava que, no conjunto da produção industrial, a absorção da mão-de-obra feminina era da ordem de 33, $7 \%$. Como se sabe, o suprimento dessa força de trabalho era realizado, majoritariamente, com trabalhadoras imigrantes. Ribeiro (1988, p.154 e 158); Pena (1981, p.122). 
vadas em exame de suficiência para cursar a Escola Normal. Como agora o governo não precisa de professoras, preparam-se as meninas para ensinar, em colégios ou casas particulares, as primeiras letras, a costura, todo e qualquer serviço de agulha, bordados finos e trabalhos de gosto". ${ }^{67}$

Com a negativa do senado estadual em empreender as mudanças no Seminário, transformando-o em uma fonte de recrutamento de professoras para a escola pública preliminar, serão feitas freqüentes sugestões pelos Secretários do Interior no sentido de dar uma outra orientação ao Seminário, "mais harmônica com [...] o progresso e com as necessidades atuais da existência" e de acordo com a "condição humilde das órfãs". Em 1897, as meninas recebidas no orfanato, a partir dos 7 anos, recebiam "alguma instrução preliminar" e de "prendas domésticas" - costuras, bordados, trabalhos de lã etc. que, segundo a Secretaria do Interior, embora fossem de utilidade como prendas, tinham "pouco valor como meio de prover a subsistência”. Propunha, então, ao lado de um "programa de ensino bem delineado", a criação "de aulas especiais de música e canto; de oficinas de costura, modas, levantamento de moldes, cortes, ensino de datilografia, tipografia, fotografia; aulas de escrituração mercantil e de economia doméstica; oficinas de chapéus para senhoras, de luvas, trabalhos de floristas, etc." ${ }^{68}$ Tais oficinas, que capacitariam as asiladas para o desempenho de muitas "profissões honestas", poderiam ser organizadas com "grande economia pelo estabelecimento e utilidade para o estado", fornecendo "além de outros artigos de difícil confecção", roupas para "as enfermeiras dos numerosos hospitais militares e civis". ${ }^{69}$

${ }^{67}$ Relatório... pelo Secretário dos Negócios do Interior e Instrução Pública, Alarico da Silveira, 1.922-1.923, p. 112.

${ }^{68}$ Relatório... pelo Secretário dos Negócios do Interior e Instrução Pública, Antônio Dino da Costa Bueno, 15/3/1897.

${ }^{69}$ Relatório... pelo Secretário dos Negócios do Interior e Instrução Pública, João Baptista de Mello Peixoto, 31/3/1898. A proposta do secretário visava, provavelmente, ampliar a prática já existente no orfanato de as menores contribuírem, com o seu trabalho, para a manutenção do Seminário. Por exemplo, em 1898, a irmã diretora solicita ao estado a quantia de $3.211 \$ 200$ como pagamento "de peças de roupas feitas pelas educandas para o Hospital do Isolamento" ( $O$ ESP, Notas e Informações, 11/12/1898).
No entanto, nenhuma providência neste sentido havia sido tomada até 1906. Neste ano, o Relatório de Gustavo Godói a Jorge Tibiriçá insiste na reforma do Seminário em "estabelecimento de ensino profissional". Na verdade, o Secretário mostrava-se contrário aos rumos assumidos pela instituição que, ao invés de habilitar as meninas para "os diversos misteres, próprios do sexo e compatíveis com a modéstia de sua condição, como costureiras, lavadeiras, engomadeiras, enfermeiras, etc.", havia optado por fornecer-lhes - além dos estudos preliminares, adequados à sua situação social - também o ensino secundário. Os cursos dados no Seminário estavam organizados em três níveis, com a seguinte programação: curso infantil: leitura, caligrafia, gramática, solfejo e trabalho manual; curso primário (com duas "divisões", isto é, dois anos): leitura, caligrafia, gramática nacional, instrução cívica, aritmética, geografia, gramática francesa, história sagrada, história do Brasil, geometria, solfejo e trabalho manual; curso secundário (três divisões): instrução cívica, gramática nacional, geografia, história, aritmética, álgebra (as quatro operações), gramática francesa, história natural, geometria plana, física e química, desenho, solfejo, piano e trabalho manual. ${ }^{70}$

Até o final dos anos 20, o estabelecimento continuará a oferecer instrução secundária às internas, ao mesmo tempo em que cultivava o ensino das prendas domésticas e dos trabalhos manuais, anualmente expostos ao público para serem vendidos. ${ }^{71}$ Embora o

${ }^{70}$ Relatório... pelo Secretário de Estado dos Negócios do Interior, Gustavo de Oliveira Godoy, 1906, p. 53-54. Neste ano, estavam matriculadas no curso infantil, 17 meninas; no curso primário, 34 (12 na $1^{\text {a }}$ divisão e 22 na $2^{\text {a }}$ ); no secundário, 33 ( 9 na $1^{\text {a }}$ divisão, 10 na $2^{\mathrm{a}}$ e 14 na $3^{\mathrm{a}}$ ). Em 1912, 10 meninas freqüentavam o curso infantil; 40 o elementar; 17 o primário e 33 o secundário. Em 1918, das 100 internas, 65 estavam no curso primário e 35 no secundário.

${ }^{71}$ Comentando uma destas exposições, o Secretário de Estado afirmará em 1921: "Os numerosos visitantes mostraram-se satisfeitíssimos ao ver a grande e variada quantidade de trabalhos expostos e dignos de louvor pela sua perfeição, sendo justo destacar as artísticas pinturas em seda, a variada coleção de bordados, a confecção de roupas brancas para senhoras e crianças, e ainda uma infinidade de cousas que demonstram habilidade e aplicação das alunas". Relatório... pelo Secretário de Estado dos Negócios do Interior, Alarico Silveira, 1921, p. 47-48. 
Seminário procurasse preparar as órfãs para o desempenho de certas ocupações, elas restringiam-se a atividades como costura, bordados, flores etc., e ao serviço doméstico "indispensável” ao sexo. Aos 18 anos, quando eram - por força da lei - obrigadas a abandonar o estabelecimento, todas as moças sabiam costurar e haviam se tornado "boas donas-de-casa". ${ }^{72}$ Não se chegou, portanto, apesar das contínuas reivindicações das autoridades pertinentes, a organizar uma escola profissional na instituição. ${ }^{73}$

Por outro lado, cabe enfatizar a permanência do ensino secundário - elitizado, privativo das classes privilegiadas - durante todos estes anos no educandário. Tal situação talvez possa ser explicada pelo fato de a irmandade responsável pela direção do orfanato se encarregar também da regência dos cursos, não onerando o governo. Em meados da década de 20, havia professoras leigas cuidando da educação das órfãs, mas sem receber vencimentos, ou seja, sem nenhum proveito, "se-

${ }^{72}$ Como nos tempos do Império, as "educandas" eram encarregadas dos serviços do Seminário, técnica utilizada, e explicitamente reconhecida, como modeladora da vontade da menina: "Conserva-se o estabelecimento e suas dependências em perfeito asseio pelas educandas. Antes de começar os estudos, cada menina vai cuidar da parte que lhe foi confiada. Até as mais pequenas são iniciadas neste serviço, adquirindo assim desde cedo a qualidade tão preciosa para uma boa dona-de-casa". Relatório... pelo Secretário de Estado dos Negócios do Interior, Alarico Silveira, 1921, p. 47-48.

${ }^{73} \mathrm{Na}$ estatística apresentada pela Secretaria do Interior, apenas em 1919 o Seminário das Educandas aparece na relação das escolas que oferecem instrução profissional. Nos outros anos consta o funcionamento do ensino primário e secundário. Em 1924, o Anuário do Ensino do Estado de São Paulo refere-se à existência de cursos práticos - confecções e corte, roupas brancas, rendas e bordados, flores e artes aplicadas, malharia à mão -, indicando que se atribuía maior peso ao preparo das internas para o exercício destas ocupações, mesmo porque nesta época as alunas do orfanato passam a ter a possibilidade de freqüentar, após a conclusão dos estudos primários de 5 anos, tanto as escolas normais como as profissionais. Neste ano, matricularam-se nos cursos do Seminário 132 alunas (68 entre 7 e 12 anos, e 64 entre 12 e 16) e destas, apenas 4 cursavam o $5^{\circ}$ ano (curso complementar), preparatório aos cursos normais ou profissionais. não o cumprimento do dever, e a realização da maior das virtudes, a caridade". ${ }^{74}$

Além disso, as órfãs continuavam a ser requisitadas pelo governo do estado para o exercício do magistério público ou particular, e a organização dos cursos vinha contemplar estes objetivos. Os dados apresentados pela instituição a respeito do destino de suas egressas mostram que um número significativo de moças dirigiase para a Escola Normal a fim de terminar os estudos ou, como foi visto, empregavam-se como professoras em colégios ou casas particulares. Entretanto, nem todas as órfãs chegavam a cursar, no estabelecimento, o nível secundário e, posteriormente, o ensino normal. Tudo indica a existência de uma seleção, apoiada no aproveitamento escolar da menina, em suas "aptidões" ou "dotes naturais", ou, ainda, na influência de seus protetores ou tutores. ${ }^{75}$ Outras tantas meninas, ao atingirem a maioridade, eram requisitadas para "auxiliarem nos serviços domésticos" das famílias ricas, incluindo-se nestas a de seus próprios tutores. Às vezes, voltavam para a companhia da mãe viúva, para auxiliá-la no sustento da própria família ou, ainda, para se casar. Desde a sua inauguração até os anos 30, foi possível localizar apenas um

${ }^{74}$ Relatório... pelo Secretário dos Negócios do Interior, Alarico Silveira, 1921, p. 47-48. É preciso lembrar, também, que o Seminário obedecia as mesmas normas de instrução dos demais colégios mantidos pelas Irmãs de São José de Chambery.

${ }^{75}$ No Império e durante certo período, as educandas eram classificadas em duas modalidades de clientela: as pensionistas - que contribuíam com certa quantia - e as órfãs. Posteriormente, a classificação desaparece dos relatórios da irmã diretora do estabelecimento. No entanto, há informações de que meninas provenientes de famílias repentinamente empobrecidas recorressem ao Seminário. (Relatório do Seminário de Nossa Senhora da Glória, dirigido pela Irmã Luiza Antonia Janin, 1909, p.34). As vagas - limitadas a 100 - eram bastante disputadas e as órfãs tuteladas por famílias "importantes" eram, provavelmente, as favorecidas. Em 1897, o relatório de Cesário Motta Jr. informa que, através de portaria, o governo determinava a admissão das menores protegidas de F. Paes de Barros, do Desembargador Joaquim Pedro Villaça, de José Augusto Pereira de Queiroz, entre mais algumas outras. Outro aspecto a ser considerado é a inexistência de meninas de nacionalidade estrangeira no orfanato. Em 1927, entre as 132 meninas, havia apenas uma, de nacionalidade portuguesa. 
caso de egressa do educandário empregada como "contramestre em casa de modas". Por essa época, as opções pela continuidade dos estudos incluíam, além da escola normal, os cursos comerciais. ${ }^{76}$

Quanto às normas de funcionamento do Seminário, bem pouco parece ter mudado desde sua criação. Conservando-se sob orientação religiosa, o estabelecimento mantinha as menores em regime de semi-reclusão, de acordo com as regras da Ordem de São José. Até a maioridade, o contato das internas com o mundo exterior era mínimo, reduzindo-se aos parentes e tutores. E, até os anos 30 , as moças só freqüentavam escolas fora do educandário na companhia dos responsáveis e, de preferência - como acabou predominando - após deixarem o orfanato. $^{77}$

Como no período Imperial, a instituição enfrentou momentos de grandes dificuldades econômicas. Em 1897, a diretora apelava dramaticamente a Campos Salles para que providenciasse um novo prédio para o asilo, pois aquele que abrigava "as pobres órfãs", "filhas adotivas do presidente da Província”, não oferecia condições de acomodação e de higiene, colocando em

${ }^{76}$ Através dos Relatórios da Secretaria dos Negócios do Interior, anos 1893, 1894, 1896 1911, 1917, 1920, 1921, 1922, 1927 e 1930, foi feito um levantamento para melhor observar o destino das egressas. Nestes anos, saíram: 26 para casamento, 35 para professoras em escolas, colégios particulares ou em casas de família; 31 para a companhia de pais ou protetores; 9 para serviços domésticos (número que será consideravelmente maior se forem consideradas as moças solicitadas pelos tutores para exercerem estas ocupações); 11 para a companhia das mães; 1 para emprego no comércio; 3 para modistas; 1 por doença; 39 para continuarem os estudos - 27 em escolas normais, 2 em escolas comerciais e 10 sem especificação; 19 com destino desconhecido. As menores recebiam do governo, ao deixarem a instituição, uma determinada quantia para ajudá-las a se manter até começarem a trabalhar. Em 1927, as educandas que haviam escolhido o magistério receberam 200\$000; as que se casaram foram auxiliadas na compra do enxoval com $400 \$ 000$.

${ }^{77} \mathrm{O}$ isolamento em relação ao mundo exterior chegava a prejudicar algumas moças, as quais - segundo depoimento da diretora do Seminário - não atingiam bons resultados nos exames de suficiência para a regência de cadeiras de ensino público "por causa de sua timidez natural". Relatório da Diretora do Seminário da Glória, Irmã Luiza Antonia Janin, ao Presidente do Estado de São Paulo, 1897, p. 3-7. risco a saúde das menores: "O edifício, muito velho e quase que totalmente solapado pelas escavações feitas pelos ratos, que povoam os baixos dos assoalhos, onde tem seus ninhos; fazem suas tocas nas fendas dos muros, que são todos de taipas, e por essas fendas enormes passeiam pelos telhados e forros, saindo desses lugares de noite penetrando nos quartos, invadindo os armários, causando por toda a parte enormes prejuízos, deixando os mais tristes e asquerosos sulcos de sua passagem. Um exército aguerrido e pronto para ferir combate não produziria tantos estragos: roupas, vestidos, meias, sapatos, tudo estragam e despedaçam. Nada lhes resiste. Parece incrível, mas é a pura verdade o que levo dito. E em muitos lugares recônditos da casa revolvem-se os gusanos e os vermes. Confiava muitíssimo nas promessas que me foram feitas e tantas vezes reiteradas; mas não sei o que me aguarda o futuro". ${ }^{78}$

O Seminário foi transferido para um novo prédio, aumentaram-se as subvenções, mas mesmo assim continuará a se debater com a insuficiência de recursos. ${ }^{79}$ E subsistiu, assumindo enquanto instituição pública a importância histórica de ter sido o primeiro e único estabelecimento, até a criação da Escola Normal mista, em 1880, a dirigir alunas ao magistério público. Durante todo o primeiro período republicano, de lá ainda sairão as "professorinhas" das escolas isoladas suburbanas e rurais para instruir outras tantas pessoas semelhantes a elas, "desprovidas da sorte e da fortuna".

\section{Tempospresentes: onde estão as crianças?}

Este artigo pretende contribuir para o resgate de uma das presenças silenciosas na história do país - a criança. Não se trata, como se viu, de qualquer criança,

${ }^{78}$ Relatório da Diretora do Seminário da Glória, Irmã Luiza Antonia Janin, ao Presidente do Estado de São Paulo, 1897, p. 3-7.

${ }^{79}$ Em 1927, por exemplo, o governo destinava 1.165:892\$000 à Escola Normal; 509:302\$000 ao Ginásio da Capital; 354:700\$000 e 462:705\$000, respectivamente, para as Escolas Profissionais Masculina e Feminina da Capital e 174:240\$000 para o Seminário das Educandas - o que indica as prioridades da política educacional do estado. Relatório... pelo Secretário dos Negócios do Interior, Fábio de Sá Barreto, 1927, p.116. 
mas da criança pobre, exposta à brutalidade, à violência das relações sociais em decorrência da forma assumida pela expansão capitalista. Refere-se às sucessivas gerações de crianças que tiveram sua cidadania negada através da usurpação de seus direitos fundamentais.

Os flagrantes do passado aqui nomeados tratam de processos sociais que, de diversas maneiras, violentaram e exploraram a vida da criança. Em diferentes momentos históricos, no abandono das ruas, vítimas da indiferença oficial, ou encerradas em instituições disciplinares e submetidas à pedagogia da violência, ao estigma da pobreza e da exclusão, ou ainda jogadas precocemente à brutalidade de relações de trabalho próximas à da escravidão - na lavoura, na indústria ou no trabalho doméstico -, em todos os casos, as crianças tiveram as infâncias suprimidas e as vidas mutiladas.

No entanto, as crianças presentes neste relato, protagonistas dos acontecimentos, não falam elas próprias de sua condição. Essas multidões de crianças mudas nos aparecem através da fala dos outros: daqueles que exercem o poder, da burocracia do Estado, das instituições que as submetem, de seus tutores e de alguns raros educadores que se esforçam na denúncia da desgraça que marca seu destino social inaceitável.

E, todavia, ao procurar resgatar o passado através dos documentos históricos, da fala de adultos, únicos testemunhos dessa presença infantil, emerge o seu silêncio dolorosamente audível, não só revelador da tragédia de suas vidas carentes de direitos, respeito e afeto, mas, principalmente, inquiridor, portador de problemas a serem respondidos.

Tal como o fizeram os educadores do início do século, pode-se perguntar: onde estão as crianças? E, tal como eles, encontramos, em resposta, o constrangimento da tragédia social. Hoje como ontem, os modos de existência dos meninos e meninas pertencentes a grupos e classes expropriadas da população e o tratamento a eles dirigido pouco se modificaram.

No tempo presente, quando as políticas neoliberais e a lógica inexorável da acumulação ilimitada do capital fazem aumentar a pobreza e a exclusão social, suprimindo direitos arduamente conquistados pelos trabalhadores, a face mais cruel e visível da sociedade brasileira, crescentemente vincada pelo desemprego e pela desi- gualdade, encontra-se na situação de pobreza e abandono de nossas crianças. Transformadas em meninos de rua, vítimas da violência de pistoleiros e policiais, brutalizadas em estabelecimentos penais, onde são punidas pela "criminalização de seu comportamento" e onde se reafirma sua condição de excluídos e de "adultos precoces", de "réus precoces", ${ }^{80} \mathrm{ou}$, ainda, convertidas em mão-de-obra barata, explorada à exaustão em condições desumanas de trabalho, elas permanecem, como nas gerações anteriores, crianças privadas de sua infância, confinadas a uma existência sem futuro, à impossibilidade da cidadania.

É verdade que, contra essa realidade social, surgiram algumas medidas reativas. Observa-se, nos últimos anos, no âmbito do processo de reconstitucionalização do país, o desenvolvimento de políticas de atenção à infância, orientadas por uma nova concepção, a da criança como sujeito de direitos - a promulgação do Estatuto da Criança e do Adolescente (1990), a criação dos Conselhos de Direitos das Crianças e dos Fundos dos Direitos. As leis, estudos e intervenções sobre a situação da criança e do trabalho infantil apontam para medidas que viabilizem a retirada de milhares de crianças do trabalho e a oferta de educação escolar de qualidade, além de programas sociais complementares na esfera da cultura e do lazer (Pereira, 1999a).

No entanto, foram poucas as políticas públicas implementadas nessa direção. A criança pobre não se tornou prioridade governamental e não houve melhoria nas suas condições de vida. Ao contrário, a crise econômica tem aumentado o número e a indigência dessas crianças.

Alguns indicadores auxiliam a visualizar a gravidade da situação. Em 1995, a população brasileira atingiu 152 milhões de habitantes, 49 milhões na faixa de até 14 anos de idade e, entre estas, 19 milhões viviam em famílias com renda per capita inferior a meio salário mínimo. Nessa época, o Brasil tinha aproximadamente 9 milhões de crianças e adolescentes - de 5 a 17 anos de idade - trabalhando (6 milhões de meninos e 3 milhões de meninas). Entre elas, 3.500 .000 possuíam entre 10 e 14 anos. Grande parte dos trabalhadores co-

${ }^{80}$ Sobre essa questão, consultar Martins, 1991, p. 9-18 e Adorno, 1991, p. 181-208. 
meçou muito cedo. Das 74.138.441 pessoas que compõem a nossa População Economicamente Ativa (PEA), $86 \%$ começaram a trabalhar antes dos 17 anos, 28\% antes dos 14 , e $20 \%$ antes dos 9 anos. ${ }^{81}$

Segundo os dados levantados, $44 \%$ das crianças trabalhadoras atuam no campo e $13 \%$ exercem atividades urbanas. ${ }^{82}$ Além disso, enfrentam longas jornadas de trabalho: dos trabalhadores de 10 a 14 anos, 24\% trabalham 40 horas ou mais por semana, e a faixa de 15 a 17 anos atinge a cifra de $63 \%$. A atividade principal das meninas trabalhadoras é o trabalho doméstico: há 822 mil trabalhadores domésticos entre 10 e 17 anos, a grande maioria do sexo feminino. ${ }^{83}$

É importante lembrar que o uso da mão-de-obra infantil é realizado na economia formal e informal e, também, na chamada "economia clandestina" (rota de exclusão), como no tráfico de drogas, prostituição, "esmolação profissional" nos faróis das avenidas das grandes cidades, e em outras espécies variadas de serviços e "bicos" (Pereira, Carvalho et al. 1994) - realidade que ainda conhecemos muito pouco.

A inserção das crianças no mundo do trabalho impede-as do acesso ou freqüência à escola. Do total de 21 milhões de analfabetos em 1995, por volta de 3 milhões estavam na faixa dos 7 aos 9 anos (30\% da faixa etária correspondente); 1.750 .000 , entre 10 e 14 anos (10\% da faixa de idade); e 16 milhões apresentavam 15 anos ou mais. Se levarmos em conta os anos de estudo das pessoas com 10 anos ou mais de idade, veremos que $35 \%$ delas têm apenas entre 4 e 7 anos e $37 \%$ estudaram menos de 3 anos. ${ }^{84}$

${ }^{81}$ Os dados estatísticos apresentados no texto são baseados no Censo Demográfico e PNAD/1995 - Pesquisa Nacional de Amostras de Domicílios, realizados pelo IBGE e trabalhados pelo DIEESE Departamento Intersindical de Estatística e Estudos Sócio-Econômicos, Anuário dos Trabalhadores - 1996/1997, São Paulo: DIEESE, 1966, p. 60-64 e 82. Não está incluída a população de Rondônia, Acre, Amazônia, Roraima, Pará e Amapá.

${ }^{82}$ Idem, p. 82.

${ }^{83}$ IBGE -PNAD/1995. Indicadores sobre crianças e adolescentes. Brasil, 1991-1996. Brasília/Rio de Janeiro: UNICEF/IBGE, 1997, apud Rizzini, 1999.

${ }^{84}$ Censo Demográfico - PNAD/IBGE - 1995. Elaboração DIEESE - Departamento Intersindical de Estatística e Estudos Só-
Por outro lado, segundo informações do MEC, em 1998, do total de 41.878 .482 alunos atendidos pela escola pública, $77,5 \%$ eram do ensino fundamental (32.400.000), 8,8\% da pré-escola e classes de alfabetização e 13, 7\% do ensino médio (5.740.000), indicando baixo atendimento nos dois últimos níveis de ensino para a população em idade própria. Com relação ao ensino médio, apenas 16\% dos jovens entre 15 e 18 anos concluíam este nível de ensino, no setor público e no privado.

$\mathrm{O}$ atendimento, no país, de jovens infratores, maiores de 12 anos, ainda é realizado na sua quase totalidade, neste final de século, pelas fundações estaduais do bem-estar do menor (91,53\%), ou mediante convênios com entidades não-governamentais e parcerias com outras instituições (1,96\%) (Pereira, 1999b, p 13).

Em 1998, havia 20.352 adolescentes entre 12 e 20 anos atendidos pelo sistema de garantia de direitos, cumprindo medidas judiciais: $18.126(89,11 \%)$ do sexo masculino e $1.500(7,37 \%)$ do sexo feminino. A faixa etária predominante situava-se entre 15 e 18 anos (75,3\%). Em relação à escolaridade dos adolescentes autores de atos infracionais, os dados indicam que $7,1 \%$ eram analfabetos e $71 \%$ não haviam concluído o ensino fundamental: $46 \%$ cursavam as primeiras séries e $25 \%$, as séries seguintes. Quanto aos crimes de que eram acusados, a maioria referia-se a ações "contra o patrimônio" $(73,8 \%)$, e, apenas $8,5 \%$ do total, a crimes de natureza grave, "contra a vida" humana. ${ }^{85}$

cio-Econômicos. Anuário dos Trabalhadores -1996/1997, São Paulo: DIEESE, 1996, p. 60-61. Não está incluída a população de Rondônia, Acre, Amazônia, Roraima, Pará e Amapá.

${ }^{85}$ Caderno do Ministério da Justiça/DCA/SNDH - Atendimento ao adolescente em conflito com a lei: reflexões para uma prática qualificada, 1998, Brasília, apud Pereira (1999b). De acordo com Pereira (1999b), "em todo o país, apenas 4\% dos adolescentes sob medida educativa concluíram o ensino fundamental. $0,3 \%$ estão cursando o ensino médio e $1,8 \%$ já o concluíram e, $0,03 \%$ estão no ensino superior". Segundo a autora, não há informações sobre a escolarização de adolescentes com medidas judiciais, "por não terem as unidades da federação respondido a essa situação". Além disso, embora o Estatuto da Criança e do Adolescente estabeleça a obrigatoriedade do projeto pedagógico em cada unidade de atendimento, tal determinação não é observada na maioria das unidades: apenas 39,9\% afirmaram pos- 
No que diz respeito aos internos da FEBEM, em São Paulo, os dados disponíveis mostram que, nesse mesmo período, havia 3 mil adolescentes internos, 96,2\% do sexo masculino e $3,8 \%$ do sexo feminino $(62,7 \%$, em primeira internação, e, 37,3\%, reincidentes). Sobre a idade dos adolescentes, $11,7 \%$ tinham 15 anos; 22,8\%, 16 anos; 30,6\%, 17 anos; e, 23,4\%, 18 anos. Ainda sobre o perfil dessas crianças e adolescentes, os indicadores mostram que 59,5\% eram de cor branca; 20, 9\%, negra; e, 19,4\%, parda. Quanto à escolaridade, 53,91\% estavam estudando quando foram para a instituição e, $46,09 \%$ dos que lá se encontravam não estudavam. Sobre o nível de instrução dos internos, 60,49\% estavam entre a $5^{\underline{a}}$ e a $8^{\underline{a}}$ séries; $23 \%$, entre a $1^{\underline{a}}$ e a $4^{\mathrm{a}}$ séries; $16,5 \%$, no ensino médio. No que se refere aos motivos da aplicação da medida de internação, observa-se que, acompanhando as tendências nacionais, a minoria é responsabilizada por homicídios $(5,1 \%) ; 61 \%$ acusados de roubo; $5,4 \%$, de furto e $4,8 \%$, de tráfico de drogas. ${ }^{86}$

Diante desse quadro de devastação da infância, somente a democratização da sociedade e a ampliação e publicização do espaço público poderão ensejar mudanças, através de ações que visem o desenvolvimento econômico, a geração de empregos, a implantação de políticas sociais de saúde, educação, cultura e habitação voltadas à maioria da população. A realização da cidadania e a consolidação da democracia significam a possibilidade de retirar do abandono milhares de famílias e impedir a mutilação de suas crianças.

Nessa perspectiva, este texto - ao resgatar uma pequena parte da trajetória de vida desses meninos e meninas sem infância - pretende contribuir para o conhecimento histórico dos processos sociais que os têm violentado, na esperança de que assim possam ser criadas as possibilidades de sua superação.

suir projeto pedagógico em execução, $28,5 \%$ disseram não possuir qualquer projeto de atendimento e $31,5 \%$ sequer responderam a esse quesito no relatório do Ministério da Justiça/Departamento da Criança. Agradeço a Irandi Pereira por ter viabilizado a apresentação, neste trabalho, de dados relativos aos adolescentes infratores.

${ }^{86}$ O Estado de S. Paulo, 13/09/99; e Ministério Público Estadual de São Paulo, julho de 1997 a julho de 1998, apud Pereira (1999).
CARMEN SYLVIA VIDIGAL MORAES é doutora em Sociologia pela Faculdade de Filosofia, Letras e Ciências Humanas da Universidade de São Paulo. Professora na Faculdade de Educação da USP. Membro da Coordenação do Centro de Memória da Educação da FEUSP e Coordenadora da Área Temática do Programa de PósGraduação "Estado, Sociedade, Educação". Linhas de pesquisa: História e Sociologia da Educação; História das Práticas Escolares; Relação Trabalho e Educação, Ensino Técnico/Formação Profissional; Políticas Públicas.

E-mail: moraescs@usp.br

\section{Referências Bibliográficas}

ADORNO, Sérgio, (1991). A experiência precoce de punição. In: MARTINS, José de S., O massacre dos inocentes; a criança sem infância noi Brasil. São Paulo: Hucitec.

ALMEIDA JÚNIOR, A., (1933). O hiato nocivo na vida legal dos menores. Revista Educação, v. 1 n. 1, mar.

ANTUNHA, Heládio, (1976). A instrução pública no Estado de São Paulo: a reforma de 1920. São Paulo: Faculdade de Educação da USP (Série Estudos e Documentos).

BLANCO, Esmeralda, (1977). O trabalho da mulher e do menor na indústria paulistana (1890-1928). Dissertação de Mestrado, São Paulo: FFLCH-USP, mimeo.

BORGES, Wanda, (1980). A profissionalização feminina: uma experiência no ensino público. São Paulo: Loyola.

CANABRAVA, Alice P., (1951). O desenvolvimento da cultura do algodão na Província de São Paulo (1861-1875). São Paulo: USP.

CARVALHO, José M. de, (1977). Forças Armadas na Primeira República: o poder desestabilizador. In: FAUSTO, B., (org.). História da Civilização Brasileira. Rio de Janeiro: DIFEL. [T. III, Sociedade e Instituições (1889-1930); v. 2, O Brasil Republicano].

CUNHA, L. A., (1977). O ensino de ofícios manufatureiros em arsenais, asilos e liceus, Fórum Educacional, v.1, n.1, jan.-mar.

DIRETORIA GERAL DA INSTRUÇÃO PÚBLICA. Anuário do Ensino do Estado de são Paulo, 1918, 1919 e 1924.

ESCOBAR, José R., (1933). "Histórico da Instrução Pública Paulista”. Revista Educação, v. III-IV, n. 3-4.

FERNANDES, Heloisa, (1977). A força pública do Estado de São Paulo. In: FAUSTO, B., (org.). História da Civilização Brasileira. Rio de Janeiro: DIFEL. [T. III, Sociedade e Instituições (18891930); v. 2, O Brasil Republicano]. 
FONSECA, Celso Suckow da, (1961). História do Ensino Industrial no Brasil. Rio de Janeiro: Escola Técnica Nacional.

FOUCAULT, Michel, (1977). Vigiar e punir; história da violência nas prisões. Petrópolis: Vozes. , (1984). Microfísica do Poder. Rio de Janeiro: Graal.

GOFFMAN, Erving, (1974). Manicômios, prisões e conventos. São Paulo: Perspectiva.

GRIGNON, Claude, (1971). L'ordre des choses: les fonctions des l'enseignement technique. Paris: Minut.

HARDMAN, F. Foot, (1988). Trem fantasma; a modernidade na selva. São Paulo: Companhia das Letras.

KOWARICK, Lúcio, (1987). Trabalho e vadiagem: a origem do trabalho livre no Brasil. São Paulo: Brasiliense.

LAURINDO, Arnaldo, (1962). Cinqüenta anos de ensino profissional no Estado de São Paulo, 1911-1961. São Paulo: Fundo do Ensino Profissional.

MARTINS, José de Souza, (1979). O cativeiro da terra. São Paulo: Ed. Ciências Humanas.

, (1991). Regimar e seus amigos. A criança na luta pela terra e pela vida. In: MARTINS, José de S., O Massacre dos inocentes: a criança sem infância no Brasil. São Paulo: Hucitec.

MORAES, Carmen S. V., (1990). A socialização da força de trabalho: instrução popular e qualificação profissional no Estado de São Paulo - 1873/1934. Tese Doutorado. São Paulo: FFLCH/USP.

PENA, Maria V. J., (1981). Mulheres e trabalhadoras; presença feminina na constituição do sistema fabril. Rio de Janeiro: Paz e Terra.
PEREIRA, Irandi, (1999a). Trabalho infantil: mitos e dilemas. Dissertação de Mestrado. São Paulo: FE/USP, mimeo. , (1999b). O direito à educação de adolescentes autores de ato infracional: o caso FEBEM-SP. Projeto de Pesquisa. São Paulo: FEUSP, mimeo.

PEREIRA, Irandi, CARVALHO, M. do Carmo B. et al., (1994). Trabalho infantil: mitos e dilemas, São Paulo: Ed. Forja.

PETRONE, Maria Tereza Schorer, (1976). Imigração Assalariada. In: FAUSTO, Boris (org.). História da Civilização Brasileira O Brasil Monárquico II, v. 3. São Paulo: DIFEL. , (1977). Imigração. In: FAUSTO, Boris (org.). História da Civilização Brasileira - O Brasil Republicano, III, v. 2. São Paulo: DIFEL.

RIBEIRO, Maria Alice, (1988). Condições de trabalho na indústria têxtil paulista (1870-1930). São Paulo: Hucitec.

RIZZINI, Irma, (1999). Pequenos Trabalhadores do Brasil. In: PRIORE, Mary Del (org.). História das crianças no Brasil. São Paulo: Contexto.

SALLUM JR., Brasílio, (1982). Capitalismo e cafeicultura. Oeste Paulista: 1888-1930. São Paulo: Duas Cidades.

SANTOS, Marco A. C. dos, (1999). Criança e criminalidade no início do século. In: PRIORE, Mary Del (org.). História das crianças no Brasil. São Paulo: Contexto.

STEIN, Stanley J., (1979). Origens e evolução da indústria têxtil no Brasil. 1850-1950. Rio de Janeiro: Campus.

TANURI, Leonor M., (1979). O ensino normal em São Paulo. São Paulo: FEUSP. 